Article

\title{
Integrated Evaluation and Scenario Simulation for Forest Ecological Security of Beijing Based on System Dynamics Model
}

\author{
Fangzheng Li ${ }^{1}$, Shasha Lu ${ }^{2, *}$, Yinan Sun ${ }^{1}$, Xiong Li ${ }^{1}$, Benye $\mathrm{Xi}^{3}$ and Weiqi Liu ${ }^{1}$
}

1 School of Landscape Architecture, Beijing Forestry University, Beijing 100083, China; E-Mails: tama319@bjfu.edu.cn (F.L.); mhxiaojie@bjfu.edu.cn (Y.S.); lixiong@bjfu.edu.cn (X.L.); liuweiqi@bjfu.edu.cn (W.L.)

2 School of Economics and Management, Beijing Forestry University, Beijing 100083, China

3 Ministry of Education Key Laboratory of Silviculture and Conservation, Beijing Forestry University, Beijing 100083, China; E-Mail: benyexi@bjfu.edu.cn

* Author to whom correspondence should be addressed; E-Mail: lushasha@bjfu.edu.cn; Tel.: +86-10-62-337-196; Fax: +86-10-64-928-482.

Academic Editor: Marc A. Rosen

Received: 10 July 2015 / Accepted: 2 October 2015 / Published: 7 October 2015

\begin{abstract}
Forest Ecological Security (FES) means coordinated development of forest ecosystems, social economies, and the forest environment. In this paper, we evaluate FES in Beijing under different designed scenarios using a dynamic systems model and find that first, the initial FES index value (in Scenario 0) increased to its highest level of 0.529 in 2012 , but declined slightly to 0.485 by 2020 . Second, in Scenarios $1-4$, the FES index value reached $0.545,0.516,0.585$ and 0.637 respectively in 2020, which was enhanced in varying degrees when compared with Scenario 0. The simulation shows the implementation of forest management policies, socioeconomic development and environmental management combine to affect the FES in Beijing. The FES could develop into a good state when the productivity of forest resources, the stability of forest environments and the orderly development of the social economy are carefully maintained (in Scenario 4). This research could provide decision-making in support of the overall improvement of forest conditions while promoting sustainable forestry in Beijing.
\end{abstract}

Keywords: Beijing; forest ecological security; integrated evaluation; scenario simulation; system dynamics model 


\section{Introduction}

Socio-economic development and population growth have resulted in increased energy demands and resource consumption, creating an environmental crisis, ecological degradation, and other serious problems in China [1,2]. Extreme meteorological events and disasters, such as droughts, floods, and high temperatures have frequently occurred worldwide [3]. Maintaining ecological security has become an inevitable problem for humans in their attempts to achieve sustainable development in the 21 st century [2]. Forest ecosystems, which account for $31 \%$ of the earth's total land area, comprise the earth's largest ecosystem, and also contain the majority of earth's biomass [4]. Forests provide energy to other ecosystems for material cycling and also clean some of the waste generated by other ecosystems [5,6]. Maintaining the security of forest ecosystems is therefore essential to improving the global environment, protecting global biodiversity, and achieving sustainable socio-economic development [7].

In China, a one-sided pursuit of profits has created a growing impact on forest environments. Over the past thirty years, fragmentation of China's forest ecosystems has degraded habitat quality. The deteriorating forest environment will threaten the quality of human life and health directly [8,9]. Recently, the Chinese government has begun to attach more importance to Forest Ecological Security (FES). Forest Ecological Security (FES) means the coordinated development of forest ecosystems, social economies, and the forest environment. Currently, China's central government has stimulated and improved FES along with ecologically sound development. The Eighteenth National Congress of the Communist Party of China first proposed an overall scheme for developing an ecologically sound and socialistic civilization with Chinese characteristics. In 2015, “opinions on promoting the development of an ecologically sound civilization" issued by the State Council has pushed the development of an ecologically sound civilization to the height of reviving "the Chinese dream" [10].

Because ecological conditions have begun to deteriorate globally, a large amount of research has begun to focus on the evaluation and forecasting of ecological security [11]. Ecological security means there is no threat to human life, health and happiness; that is the ecosystem prevents potential risks caused by natural and human activities or a combination thereof [12,13]. Many researchers have gained a common interest in the evaluation of global and regional ecosystems, mainly in the fields of landscape-scale ecological security [14], land ecological security [15], water resource security [16], and food security [17]. Forecasting ecological security has also attracted the attention of researchers in different fields. Researchers have produced fruitful achievements in the fields of forecasting urban ecological security [13], monitoring and early warnings related to the ecological carrying capacity of water resources [18], early warnings related to land ecological security issues [19], analysis and forecasting of wetland system conditions [20] and early warnings of urban traffic problems and related issues [21]. However, from the forest ecosystem perspective, research on the evaluation of FES is still in its relative infancy. Little research has been conducted related to the mechanisms used to forecast FES. Therefore, the evaluation and forecasting of FES research should be strengthened.

The concept of forecasting ecological security refers to forecasting any ecosystem crisis caused by resource exploitation, human activities, and environmental pollution. This type of forecasting is based on the evaluation of an ecosystem, with the goal of taking effective measures to control any such forecasted crisis. This important field of research that evaluates and forecasts ecological security is 
relatively mature [22]. Currently, the forecasting and evaluation methods related to ecological security include principal component analysis [23], the grey relationship [24], system cluster [25], ecological footprint [26], aggregate indicator [27], and the fuzzy comprehensive evaluation [28] methods, as well as the use of neural network models [29]. Notably, these methods all employ static evaluation. However, ecological security is a dynamic process, while the factors influencing ecological security are complex and dynamic. Forecasting that is based on past history alone cannot instruct future practices and will overlook studies on the coupling analysis of changeable factors related to ecological security.

A system dynamics model was used to simulate the complex system to describe and understand the structure and behavior of FES in Beijing [30]. Forrester of the Massachusetts Institute of Technology initially proposed the use of a system dynamics (SD) model in the early 1960's. This model has been used widely in solving critical problems and improving decision making in the fields of engineering, economics, and in social and environmental sciences [31,32]. An SD model analyzes all elements of a system as a whole and represents the dynamics of a system through the interactions of variables and actors inside the structure [33]. This model accommodates characteristics such as non-linear relationships, causal loops, information feedback, and time delays in complex and dynamic problems. These features allow SD to become an especially powerful and appropriate tool for the present case study. Additionally, the SD model could better simulate and analyze the post effects under various control schemes, seeking the best way to improve the system function. In short, an SD model conceptualizes a comprehensive understanding and complicated phenomena that can combine quantitative and qualitative analysis [34,35]. Based on an SD model, this paper consequently conducts an integrated evaluation and scenario simulation for FES in Beijing.

The forest ecosystem of Beijing provides important ecosystem services supporting economic and social development, and ensures regional eco-environmental security [36]. Recently, Beijing's economy has increased rapidly, maintaining a growth rate of more than $9.5 \%$ for nine years since 2001 [37]. As a result, the demands placed on Beijing's forest resources are increasing. The production of forestry products has increased with high growth rates of $12.5 \%, 189.4 \%$ and $38.4 \%$ in 2012, 2013, and 2014, respectively, and is expected to maintain a high rate for the foreseeable future [37]. The increasing consumption of forest resources will cause a major threat to FES. The future outlook for FES conditions in Beijing is not optimistic. Therefore, analyzing the FES conditions in this city is of theoretical and practical significance. This article investigated the following three aspects:

i) Based on the definition of FES, an FES index system for Beijing was established and calculated.

ii) Based on the feedback loops of the combined forest resource socioeconomic environment system, a scenario simulation and optimizing control model (SSOCM) was established to forecast and evaluate the level of FES for Beijing from 2000 to 2020.

Four dynamic control scenario types were proposed. That is individual scenarios were oriented towards: (a) medium-speed socioeconomic development; (b) strengthening environmental management; (c) developing reasonable forest management policies; and (d) a scenario combining all three by coordinating forest resource management, the social economy, and other environmental issues. Basically we tried to select the most reasonable and effective control schemes for FES in Beijing. This paper could provide decision makers with an optimal control scheme for the comprehensive improvement of forest security and for promoting sustainable forest management. 


\section{Study Area}

Located in the northwest edge of North China Plain $\left(39^{\circ} 28^{\prime}-41^{\circ} 05^{\prime} \mathrm{N}, 115^{\circ} 25^{\prime}-117^{\circ} 30^{\prime} \mathrm{E}\right)$, Beijing is the political, economic, and cultural center of China (Figure 1). Beijing extends approximately $176 \mathrm{~km}$ from north to south and $160 \mathrm{~km}$ from east to west, with a total area of $16,410 \mathrm{~km}^{2}$. Forest ecosystems comprise $35 \%$ of the area administered by Beijing. These forests have become an important asset that helps to maintain the urban ecosystem [25]. Data from the seventh forest resources inventory show that the forest area in Beijing reached $5.20 \times 10^{5}$ ha with forests covering $37 \%$ of the city. The timber volume was $1.85 \times 10^{4} \mathrm{~m}^{3}$ [38].

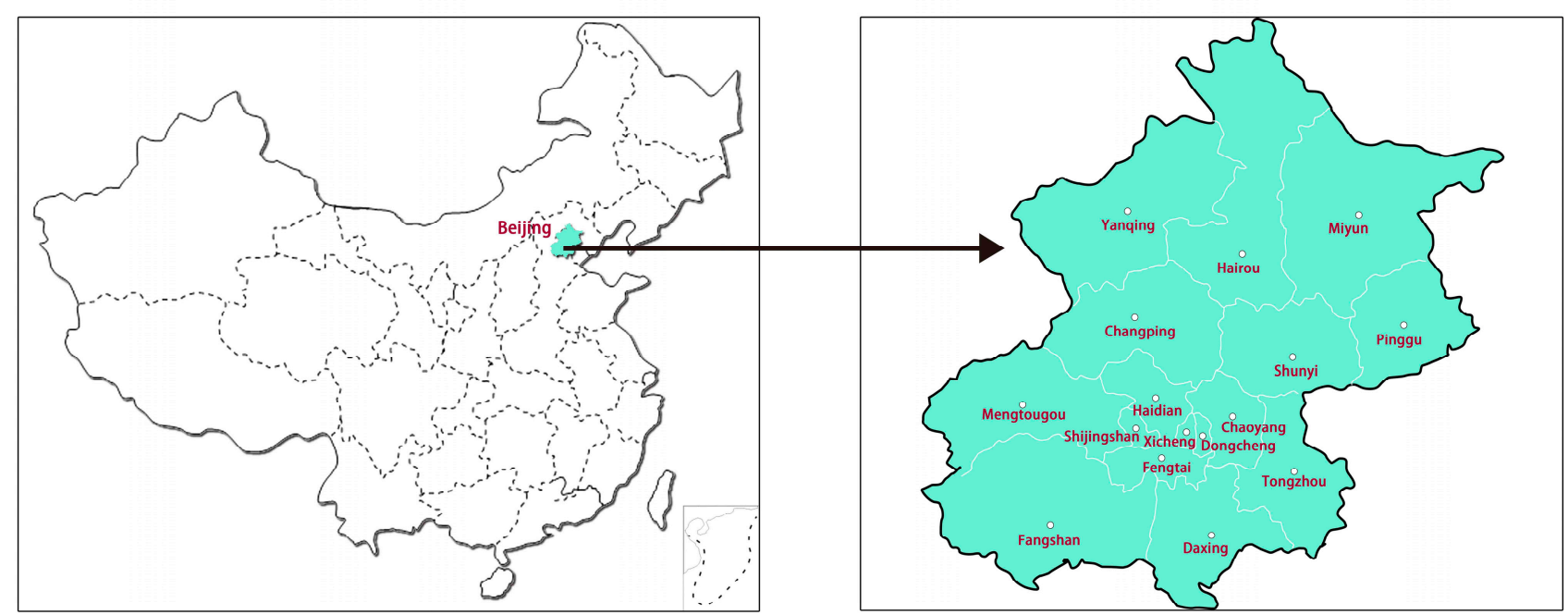

Figure 1. Study area.

Beijing's rapidly developing economy has maintained a growth rate of more than $7 \%$ in recent years, while the GDP has reached $2.13 \times 10^{12}$ Yuan [39]. With recent growth, at the end of 2014 $2.15 \times 10^{7}$ permanent residents lived in Beijing. Socio-economic development has caused deforestation and an excessive loss of forest resources. $1.23 \times 10^{5} \mathrm{~m}^{3}$ of timber were harvested in Beijing by 2013 [38]. Meanwhile, automobile exhaust and the burning of fossil fuels have led to increasingly serious air pollution in Beijing, with the annual average density of the city's airborne sulfur dioxide, nitrogen dioxide, and fine particulate matter reaching $26.5 \mu \mathrm{g} / \mathrm{m}^{3}, 56 \mu \mathrm{g} / \mathrm{m}^{3}$ and $89.5 \mu \mathrm{g} / \mathrm{m}^{3}$ [39] respectively. Air pollution could cause changes related to hydrology, nutrient cycling, erosion, microclimate and overall stability that could seriously threaten Beijing's forest ecosystems [40].

Beijing has reinforced the protection and development of FES since 2000. Special funding for FES has been established to improve the forest conditions as well as to encourage ecologically sound development. Authorities have taken advantage of city events to promote forest and ecologically sound development in Beijing. The green ratio reached 50\% during the preparations for the 2008 Beijing Olympic Games [38,41] (In China, "green ratio" $=$ [(woodland area + all shrub forest area + four side tree planting area)/land area] $\times 100 \%$ [42]). Beijing's "12th 5-Year Plan" included an afforestation of barren hills project (2012-2015), and Beijing has committed to completing afforestation of $2.67 \times 10^{4}$ ha. Since 2012, the Beijing city government has implemented an afforestation project for the plains of Beijing and has laid plans to afforest $6.67 \times 10^{4}$ ha within 5 years [43]. 


\section{Methods}

\subsection{Integrated Evaluation for FES}

\subsubsection{FES Conceptualization}

Researchers worldwide are focusing on finding ways to guarantee the healthy and sustainable development of regional ecosystems [44]. Currently, research studies have addressed forest ecosystems through forest ecological monitoring [45], forest management [46], forest ecological services and forest health evaluation $[8,9,47]$. Few studies have been conducted on an integrated evaluation of FES and the development of scenario simulations related to FES. Many researchers have addressed the concept of forest health [9,48]. A healthy forest is usually envisioned as a balanced ecosystem including a community of animals, plants and their physical environment [49]. However, forest health is normally considered from the forest's perspective and focuses on the internal forest ecosystem (e.g., maintenance of the productive capacity of forest, conservation of biological diversity and conservation and maintenance of soil and water resources in the forest [50-52], etc.). This method ignores the relationship between the forest ecosystem and its surroundings as well as the feedback from external disturbances. Therefore, the concept of forest health is unsuitable for use in assessing the sustainability of the forest ecosystem. Therefore, this article defined FES as that in a particular time and space, a forest ecosystem can achieve self-regulation, sustain the livelihoods and maintain the ability to recover from natural and human-caused stressors. In addition, FES provides the service functions to protect the environment for the survival of biological species and resources as well as meeting the needs of sustainable development of society and economy. The goal of FES is to develop a forest ecosystem that can facilitate the coordinated development of forest ecosystem, the social economy and the forest environment [53,54].

\subsubsection{Index System and Weight}

An index system was established to judge FES status as good or bad [55]. A high number for the FES index value (closer to 1.0) indicates healthy ecological forest conditions, orderly development of social economy and stable environment conditions. According to the literature and our definition of FES as a state achieving the coordinated development of forest ecosystems, the social economy and the forest environment, we composed an FES index comprising three sub-indices on the forest resource, social economy, and environment. More detailed indices that had been highlighted by previous researchers are included in the FES index system as third-tier indicator [56-70]. Because of the lack of suitable data for these indices, an FES index system was established consisting of 18 indices (Table 1).

Various indices are in the system, which have different effects on FES. Therefore, entropy weight theory is also used to determine evaluation index weights to represent the effect of each index on FES, which was an objective weighting method [71]. Finally, the relative weight of each index was obtained based on Equations (1) and (2) [71,72]. If there are $m$ indices and $n$ evaluation objects, Equation (1) was used to calculate the entropy of $i$ th index: 


$$
H_{i}=-k \sum_{j=1}^{n} f_{i j} \ln f_{i j}
$$

when $i=1,2,3, \ldots . . m, j=1,2,3, \ldots . n, f_{i j}=f_{i j} / \sum_{j=l}^{n} r_{i j}$, and $k=1 / \operatorname{lnn}$. When $f_{i j}=0, f_{i j} \ln f_{i j}=0$. where $f_{i j}$ is the proportion of the $i$ th index and $j$ th evaluation object and $H_{i}$ is the entropy of the $i$ th index.

Equation (2) was used to calculate the weight of $i$ th index:

$$
C_{2 i}=\left(1-H_{i}\right) /\left(n-\sum_{i=1}^{m} H_{i}\right)
$$

where $0 \geq C_{2 i} \geq 1, \sum_{j=1}^{m}=1$, while $C_{2 i}$ is the weight of $i$ th index. Table 1 presents the weight, explanation, formula and direction of each index.

\subsubsection{Calculation of the FES Index Value}

An FES index value was calculated based on index data which were mainly from two different sources: the forest resources inventory and the Beijing Area Statistical Yearbook (2000-2013) [38,39]. An SD model was used to simulate various future FES indices as described below.

\section{(1) Data Standardization}

The selected indices employed different units and magnitudes, which is inconvenient for FES calculation. Thus, all of the evaluation indices needed to be standardized [18]. After the maximum and minimum values were selected from the annual statistical data, the corresponding original data was standardized using Equation (3). The standardization of positive and inverse indices required different equations. For a negative or positive index, Equations (3) or (4) were used to standardize the data:

$$
\begin{aligned}
& \text { standardization data }=\frac{\text { raw data }- \text { minimum value }}{\text { maximum }- \text { minimum value }} \\
& \text { standardization data }=\frac{\text { maximum }- \text { raw data }}{\text { maximum }- \text { minimum value }}
\end{aligned}
$$

\section{(2) Calculation of the FES Index Value}

After data standardization, the scores of all the indices were summed to reflect the overall performance of the FES index value in Beijing. The FES index value could be calculated using Equation (5) [18]. The FES index value of forecast years also could be calculated based on the forecasted results below to assess the overall performance of the FES index value in Beijing,

$$
E_{j}=\sum_{i=1}^{n} \mathrm{~W}_{i} \times \mathrm{V}_{i j}
$$

where $V_{i j}$ is the standardized score of $i$ th-index in $j$ th-year; $W_{i}$ is the weight of the $i$ th-index determined by Table 1 ; and $E_{j}$ is the FES index value in $j$ th-year. 
Table 1. Forest ecological security index system table.

\begin{tabular}{|c|c|c|c|c|c|c|}
\hline $\begin{array}{l}\text { First Level } \\
\text { Indicator }\end{array}$ & $\begin{array}{c}\text { Second Level } \\
\text { Indicators }\end{array}$ & Index Name (Unit) & Explanation & Formula & Direction & Weight \\
\hline \multirow{12}{*}{$\begin{array}{c}\text { FES } \\
\text { assessment in } \\
\text { Beijing (A1) }\end{array}$} & \multirow{6}{*}{$\begin{array}{l}\text { Forest resource } \\
\qquad \text { (B1) }\end{array}$} & $\begin{array}{l}\text { C1 Forest tourism development } \\
\text { intensity index }(\%)\end{array}$ & $\begin{array}{l}\text { Forest tourism affects conservation of natural forest vegetation [56]. Developing tourism } \\
\text { becomes the main way of human occupation of forest resources. }\end{array}$ & $\begin{array}{l}\text { Forest park area/forest area in research } \\
\text { region } \times 100 \%\end{array}$ & - & 0.0621 \\
\hline & & $\begin{array}{l}\text { C2 Forest harvesting intensity } \\
\text { index }(\%)\end{array}$ & $\begin{array}{l}\text { Harvests of high intensity make forest populations declined [57]. The larger the forest } \\
\text { harvesting intensity is, the greater the pressure on forest ecosystem will be. }\end{array}$ & Harvesting quota/forest volume $\times 100 \%$ & - & 0.0354 \\
\hline & & C3 The forest coverage rate (\%) & $\begin{array}{l}\text { The forest coverage rate is an important index to reflect the occupancy of forest area. In } \\
\text { addition, changes in forest cover affect the delivery of important ecosystem services [58]. }\end{array}$ & Forest area/land survey area $\times 100 \%$ & + & 0.0684 \\
\hline & & $\begin{array}{l}\text { C4 Forest stock volume per unit land } \\
\text { area(ten thousands } \mathrm{m}^{3} / \mathrm{Ha} \text { ) }\end{array}$ & $\begin{array}{l}\text { Forest stock volume per unit land area quantifies the sources of change of forests as an } \\
\text { important indicator reflecting the quality of forest resources [59]. }\end{array}$ & $\begin{array}{l}\text { Total forest stock volume/land } \\
\text { survey area }\end{array}$ & + & 0.0682 \\
\hline & & $\begin{array}{l}\text { C5 The public welfare forest } \\
\text { proportion (\%) }\end{array}$ & $\begin{array}{l}\text { The larger the proportion is, the more effectively forests can be used to } \\
\text { reinforce ecological function [60]. }\end{array}$ & $\begin{array}{l}\text { Public welfare forest area/total } \\
\text { forest area } \times 100 \%\end{array}$ & + & 0.0500 \\
\hline & & $\begin{array}{l}\text { C6 Investment in forest resources (ten } \\
\text { thousands Yuan/Ha) }\end{array}$ & $\begin{array}{l}\text { Forest investment can intensify timber management and therefore increase the } \\
\text { timber volume [61]. }\end{array}$ & Investment in forest resources/forest area & + & 0.0903 \\
\hline & \multirow{6}{*}{$\begin{array}{l}\text { Social } \\
\text { economy } \\
\text { (B2) }\end{array}$} & $\begin{array}{l}\text { C7 Human engineering occupation of } \\
\text { land index }(\%)\end{array}$ & $\begin{array}{l}\text { Human engineering occupation of land is the main driver for flows of forest biomass } \\
\text { acquisition that can transform forest ecosystem [62]. }\end{array}$ & $\begin{array}{l}\text { (construction land/land survey area) } \times \\
(\text { forest area/land survey area) } \times 100 \%\end{array}$ & - & 0.0282 \\
\hline & & C8 Population density $(/ \mathrm{Ha})$ & $\begin{array}{l}\text { Population growth causes the landscape change including forests [63]. The larger } \\
\text { population density is, and the greater the pressure on forest ecosystem will be. }\end{array}$ & $\begin{array}{l}\text { (population at the end of each area/land } \\
\text { survey area) } \times \text { (forest area/land } \\
\text { survey area) }\end{array}$ & - & 0.0427 \\
\hline & & $\begin{array}{l}\text { C9 GDP per unit area (ten thousands } \\
\text { Yuan/Ha) }\end{array}$ & $\begin{array}{l}\text { There is a strong interaction between economic development and forest cover [64]. } \\
\text { The ultimate pursuit of forest product and other economic behavior destabilize } \\
\text { forest ecosystem. }\end{array}$ & $\begin{array}{l}(\mathrm{GDP} / \text { land survey area }) \times \\
(\text { forest area/land survey area) }\end{array}$ & - & 0.0253 \\
\hline & & C10 Industrial structure index (\%) & $\begin{array}{l}\text { Industry structure affects long term forest harvesting [65]. The development of the second } \\
\text { industry brings the utilization of resources and creates threat to forest ecosystem. }\end{array}$ & $\begin{array}{l}\text { (secondary industry GDP/GDP }) \times(\text { forest } \\
\text { area/land survey area }) \times 100 \%\end{array}$ & - & 0.0261 \\
\hline & & $\begin{array}{l}\text { C11 Population per unit } \\
\text { forest area }(/ \mathrm{Ha})\end{array}$ & The larger the population is, the larger the consumption on forest resources will be [66]. & Area population quantity/forest area & - & 0.0400 \\
\hline & & $\begin{array}{l}\text { C12 Investment rate of industrial } \\
\text { pollution control per unit GDP (\%) }\end{array}$ & $\begin{array}{l}\text { Investment of industrial pollution control promotes the air pollution control, } \\
\text { thus benefiting forest ecosystem }[40,66] \text {. }\end{array}$ & $\begin{array}{l}\text { Investment of industrial pollution control } \\
\text { completed/GDP } \times 100 \%\end{array}$ & + & 0.1133 \\
\hline
\end{tabular}


Table 1. Cont.

\begin{tabular}{|c|c|c|c|c|c|c|}
\hline $\begin{array}{l}\text { First Level } \\
\text { Indicator }\end{array}$ & $\begin{array}{c}\text { Second Level } \\
\text { Indicators }\end{array}$ & Index Name (Unit) & Explanation & Formula & Direction & Weight \\
\hline & \multirow{6}{*}{$\begin{array}{l}\text { Environment } \\
\text { (B3) }\end{array}$} & $\begin{array}{l}\text { C13 Carbon dioxide emissions index } \\
\text { (t/ha) }\end{array}$ & $\begin{array}{l}\text { Fertility can restrain the carbon sequestration to increased atmospheric } \mathrm{CO}_{2} \text {, thus bringing } \\
\text { harm to forest ecosystem [67]. }\end{array}$ & $\begin{array}{l}\text { Fossil fuel consumption } \times \text { carbon dioxide } \\
\text { emission coefficient/land survey area }\end{array}$ & - & 0.0979 \\
\hline & & $\begin{array}{l}\text { C14 Sulfur dioxide emission index } \\
\text { (t/ha) }\end{array}$ & $\begin{array}{l}\text { Air pollution by } \mathrm{SO}_{2} \text { affects } \mathrm{PH} \text { value and therefore creating threat to the forest } \\
\text { ecosystem [68]. }\end{array}$ & $\begin{array}{l}\text { Exhaust emissions of sulfur dioxide/land } \\
\text { survey area }\end{array}$ & - & 0.0400 \\
\hline & & $\begin{array}{l}\text { C15 Annual average daily particulate } \\
\text { matter }\left(\mathrm{mg} / \mathrm{m}^{3}\right)\end{array}$ & $\begin{array}{l}\text { The health of forest ecosystem is associated with particulate matter [69]. The larger the } \\
\text { annual average daily particulate matter is, the greater the pressure on forest } \\
\text { ecosystem will be. }\end{array}$ & Obtained directly & - & 0.0551 \\
\hline & & $\begin{array}{l}\text { C16 Days of air quality above grade } \\
\text { II rate (\%) }\end{array}$ & $\begin{array}{l}\text { Days of air quality above grade II rate represent the ability to purify air in forest } \\
\text { ecosystem [40]. }\end{array}$ & Days of air quality above grade II/days & + & 0.0482 \\
\hline & & C17 Annual rainfall (hundred mm) & $\begin{array}{l}\text { Annual rainfall is associated with soil water storage in forest ecosystem and the soil water } \\
\text { balance is an important criterion for the evaluation of forest ecosystems [69]. }\end{array}$ & Obtained directly & + & 0.0449 \\
\hline & & $\begin{array}{l}\text { C18 Investment of environmental } \\
\text { protection completed index (ten } \\
\text { thousands Yuan/ha) }\end{array}$ & $\begin{array}{l}\text { Investment of environmental protection promotes the urban environment, thus benefiting } \\
\text { forest ecosystem. }\end{array}$ & $\begin{array}{l}\text { Investment of environmental protection } \\
\text { completed/GDP }\end{array}$ & + & 0.0641 \\
\hline
\end{tabular}

Note: Variables in the system have different effect on FES. When the index has positive or negative effect on FES, we use "+" i or "-" to indicate the direction respectively. 


\subsection{The Establishment of the Scenario Simulation and Optimizing Control Model}

SD depicts the interactions between the elements of the system through causal loops providing a holistic approach for analyzing the management of complex systems [73]. The SD framework is described in five steps.

(i) Observe and analyze the system studied and then identify the objectives and proper variables.

(ii) Determine the flowchart of the system and establish a series of causal feedback relationships to show interactions between variables and build a feedback structure [18,74]. In actuality, the flowchart depicts the feedback structure via graphics, creating a visual approach to show the interactions between all variables in the system. In addition, we use the flow direction to represent positive or negative effects on certain variables in a causal feedback loop. Variables are increased or decreased accumulations via flows. Meanwhile, auxiliary variables can affect the rate of a flow [75].

(iii) Establish a group of mathematical equations to describe the relationships between the variables in the system quantitatively [74]. All the mathematical equations will be created by Vensim PLE software combined with the flowchart. SD equations are differential equations which can describe a recursive relationship from a known initial state to the next state that we determine [18].

(iv) Test and verify the model. The test is to check whether the model can depict the behavior of the system. Testing must be done by comparing the values and trends of variables with historical data [55,75].

(v) Establish a simulation platform to forecast the trends of the system and design different policies and plans which simulate different state of the system [18].

\subsubsection{Methods Used to Establish the SSOCM}

Based on the system dynamics, the methods used to establish the SSOCM for FES follow:

(i) An essential aim of this paper is gaining a better understanding of the dynamic interactions between forest resources, the social economy, and the environment. Therefore, an SD model was used as a simulation platform of the SSOCM, which could represent the interactions within the forest's resource-social, economy-environment, compound system through causal feedback. Therefore, the SSOCM would realize the geared control of FES using the mathematical relationship between factors within the system.

(ii) The SSOCM simulated system performance from 2000 to 2020 by appropriately altering the variables in relation to forest policies, the social economy, and environment all of which could influence FES. Considering the current situation discussed in the introduction, strategies and plans need to be considered to improve the FES of Beijing. We therefore formulated four dynamic control scenarios to test their performance in the SD model. Individual scenarios were oriented towards: (a) medium-speed socioeconomic development; (b) strengthening environmental management; (c) developing reasonable forest management policies; and (d) a scenario combining all three by coordinating forest resource management, the social economy, and other environmental issues. Then the development trend of FES was analyzed under each different control scheme.

(iii) From the perspective of coordinated development of a forest resource-social economy-environment system, we chose the optimal control scheme and proposed a sustainable development mode of FES in Beijing. 


\subsubsection{Establishment of the SSOCM Flowchart}

To simulate the dynamic control schemes, an SSOCM was developed using Vensim PLE software. Based on the concept of FES in this article and the FES index system described above, we divided the SSOCM of FES into three subsystems: (a) forest resource; (b) socioeconomic; and (c) environment subsystems. These subsystems posit specific causal relationships among variables that affected FES, which guided the behavior of the overall system and could be used to diagnose phenomena, explain processes and predict outcomes [70]. First, we must clarify the relationships between the variables which are the initial indices constituting FES. A constitutive relationship can be identified when a variable is a constituent of the subsystem [55]. For instance, total forest area, public welfare forest area, forestry completed investment, and forest park area are constituents of a forest resource subsystem. These variables can be included into the forest resource subsystem. The other relationship called an influential relationship can be identified when the variables cannot be included into the same subsystem, but a variable influences another variable's state [55]. For instance, GDP is not a constituent of a forest resource subsystem, but it could influence forestry completed investment. Thus, GDP has an influential relationship with forestry completed investment. Thus, the flowchart of SSOCM (Figure 2) could be developed based on the relationships between variables. Both constitutive and influential relationships should be included in the flowchart. The initial values of the main variables in the model were based on data collected from 2000 to 2013 [37,38]. Moreover, parts of main constants and the value of table functions were based on the target of the 11th and 12th 5-Year Plans of Beijing for economic and social development on a national level. 


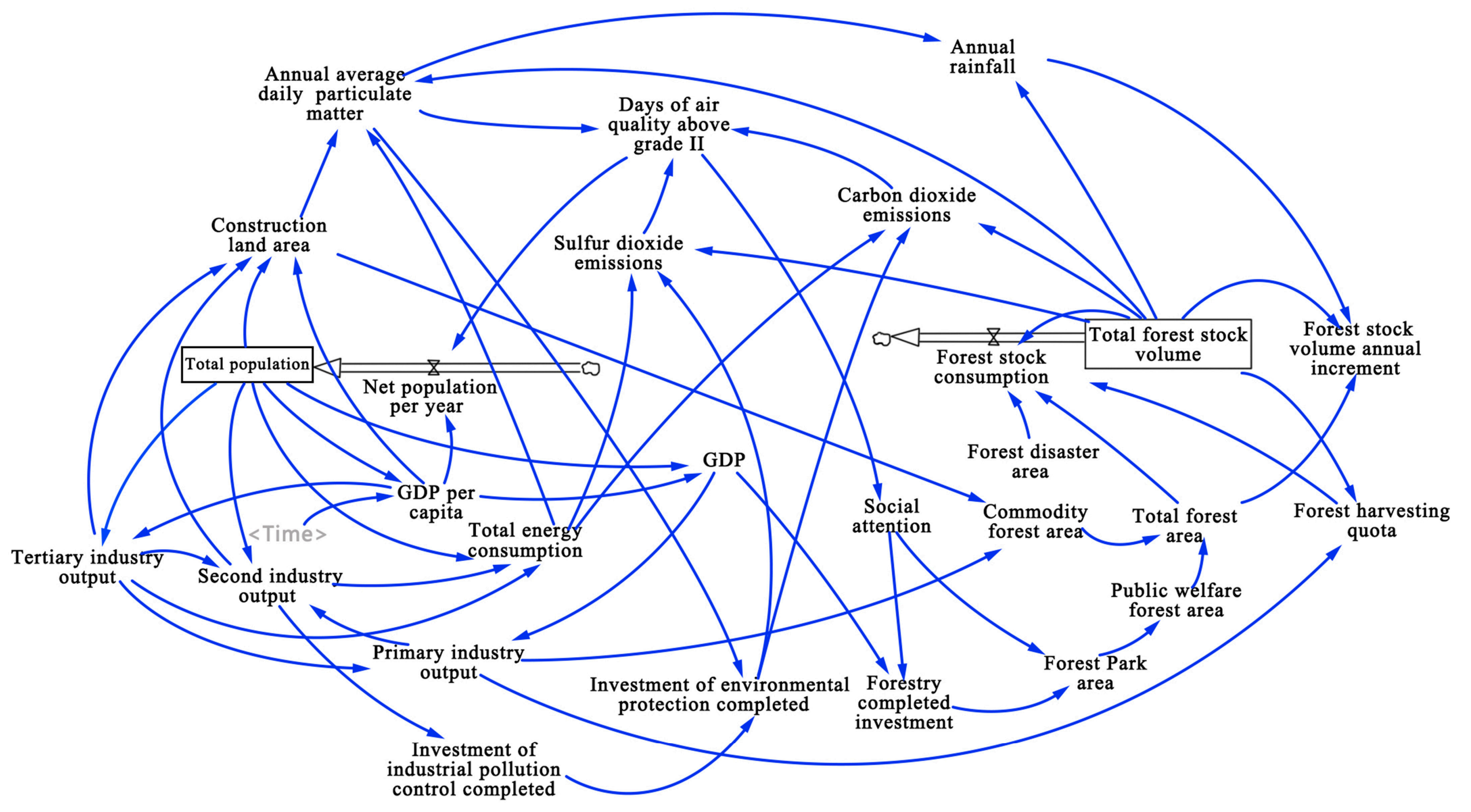

Figure 2. System dynamics flowchart of forest ecological security of Beijing. 


\subsubsection{Establishment of the SSOCM Subsystems}

\section{(1) Forest Resource Subsystem}

The forest resource subsystem supplies resources for the socioeconomic subsystem and ecological services function for the environment subsystem [76]. Therefore, the health condition and development potential of the forest resource subsystem is a significant foundation of FES. Also, this subsystem is the core component of FES, which is mainly affected by forest resource conditions (e.g., quantity and quality of forest resources and the forest resource management policies). Thus, we defined total forest stock volume as a state variable to represent the forest resources, thereby reflecting the security level of the FES. This subsystem mainly simulates the interactive relationship between forest stock volume and forest disaster area, forest harvesting quota, investment in forest resources, forest park area, public welfare forest area, commodity forest area or total forest area. Two main factors affect total forest stock volume. First, we defined the fluctuation of forest resources as intrinsic factors, which caused the growth or decline of the forest stock volume. Second, extrinsic factors (e.g., disasters, anthropogenic deforestation or conservation) also affected total forest stock volume. Implementation of beneficial forestry policies and the development of forestry projects increased the total forest area, which caused forest stock volume to increase [77]. Meanwhile, human production activities (e.g., deforestation) caused forest stock volume to decline by consuming forest resources. Moreover, when people become aware of fluctuations in forest stock volume and then take action to improve the development of the city's forest and to conduct afforestation, this increases the forest area and thereby increasing total forest stock volume. Figure 3 shows the forest resource subsystem flowchart.

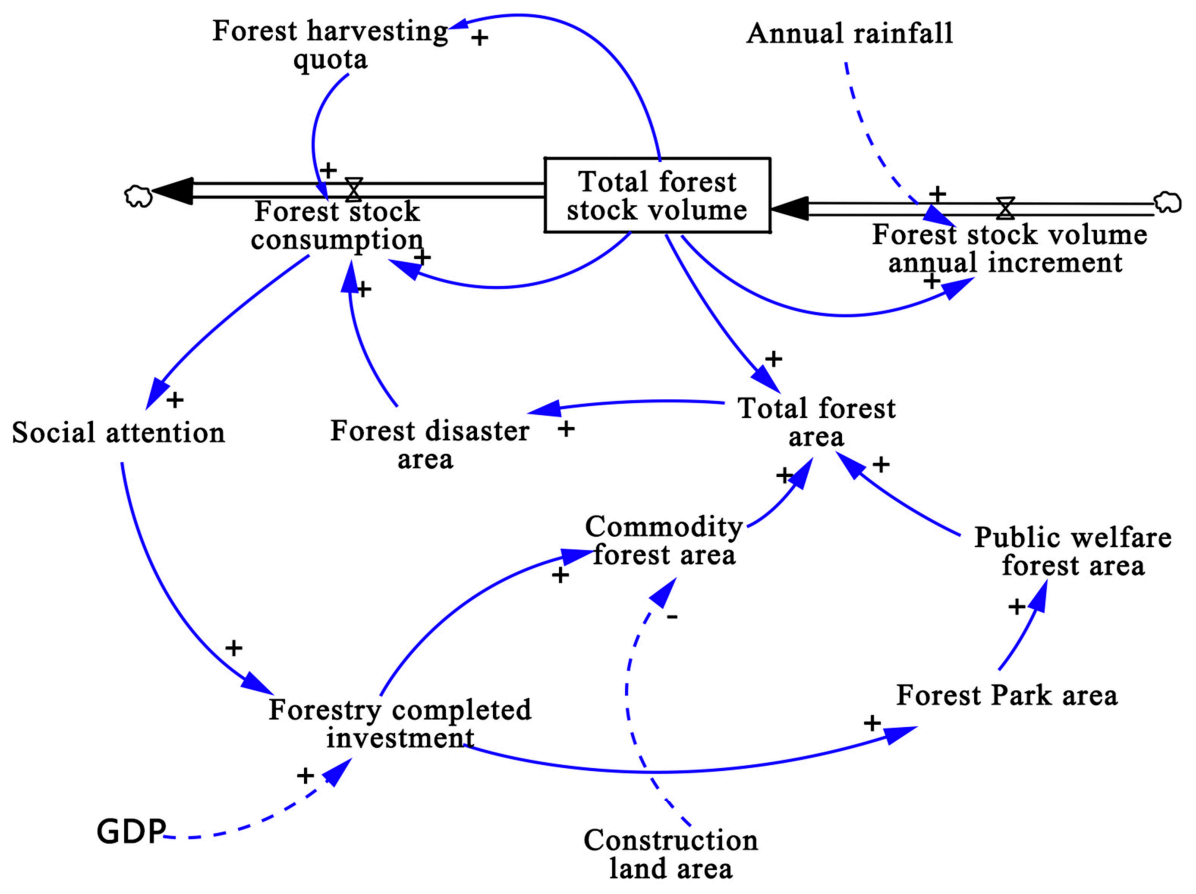

Figure 3. Flowchart of system dynamics of the forest resource subsystem of Beijing.

Causal feedback relationships: 
(1) Total forest stock volume $\rightarrow+$ forest stock volume annual increment $\rightarrow+$ total forest stock volume

(2) Total forest stock volume $\rightarrow+$ forest stock consumption $\rightarrow$ - total forest stock volume

(3) Total forest stock volume $\rightarrow+$ forest harvesting quota $\rightarrow+$ forest stock consumption $\rightarrow-$ total forest stock volume

(4) Total forest stock volume $\rightarrow+$ total forest area $\rightarrow+$ forest disaster area $\rightarrow+$ forest stock consumption $\rightarrow$ - total forest stock volume

(5) Total forest area $\rightarrow+$ forest disaster area $\rightarrow+$ forest stock consumption $\rightarrow+$ social attention $\rightarrow+$ investment in forest resources $\rightarrow+$ commodity forest area $\rightarrow+$ total forest area

(6) Total forest area $\rightarrow+$ forest disaster area $\rightarrow+$ forest stock consumption $\rightarrow+$ social attention $\rightarrow+$ investment in forest resources $\rightarrow+$ forest park area $\rightarrow+$ the public welfare forest area $\rightarrow+$ total forest area

Equations expressing the forest resource subsystem are available as Appendix A.

\section{(2) Socioeconomic Subsystem}

The socioeconomic subsystem affects forest resources and regulates the effects on the environment. However, this subsystem restricts the development of the forest resource subsystem when forest resource consumption is unrestrained. Therefore, a complex and dynamic relationship exists between natural resources, the social economy, and the environment [78]. The interactive relationship between total population and socioeconomic activities is mainly simulated in the socioeconomic subsystem. First, people pursue many activities (e.g., engaging in primary, secondary and tertiary industry production activities) for economic benefits by occupying land and consuming resources [63]. In turn, people, as the subject of production activities, supply labor and techniques for promoting social and economic development, thus creating higher GDP. Meanwhile, the development of GDP improves public infrastructure, thereby encouraging more people to immigrate to the city. This immigration then leads to a lower GDP per capita and creates greater pressure on FES. Figure 4 shows the socioeconomic subsystem flowchart.

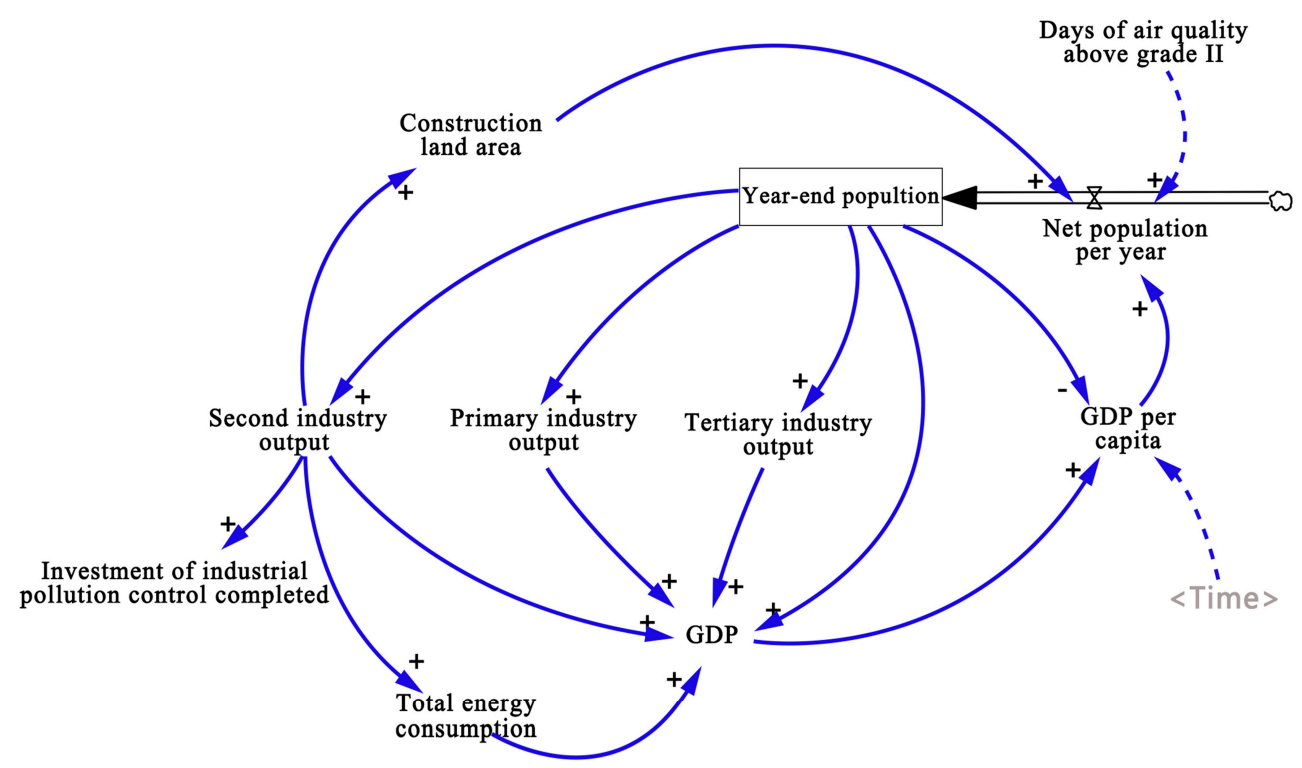

Figure 4. Flowchart of system dynamics of the socioeconomic subsystem of Beijing. 
Causal feedback relationships:

(1) Year-end population $\rightarrow$ - GDP per capita $\rightarrow+$ net population per year $\rightarrow+$ year-end population

(2) Year-end population $\rightarrow+$ secondary industry output $\rightarrow+$ construction land area $\rightarrow+$ net population per year $\rightarrow+$ year-end population

(3) Year-end population $\rightarrow+$ secondary industry output $\rightarrow+$ total energy consumption $\rightarrow+$ GDP $\rightarrow+$ GDP per capita $\rightarrow+$ net population per year $\rightarrow+$ year-end population

(4) Year-end population $\rightarrow+$ primary industry output $\rightarrow+\mathrm{GDP} \rightarrow+$ GDP per capita $\rightarrow+$ net population per year $\rightarrow+$ year-end population

(5) Year-end population $\rightarrow+$ tertiary industry output $\rightarrow+$ GDP $\rightarrow+$ GDP per capita $\rightarrow+$ net population per year $\rightarrow+$ year-end population

Equations expressing the socioeconomic subsystem are available as Appendix B.

\section{(3) Environment Subsystem}

The environment subsystem affects the state of forest resources, which significantly influences social development [79]. Meanwhile, the environment subsystem connects the socioeconomic and forest resource subsystems, thereby making this subsystem an important factor in the overall system. The environment subsystem mainly simulates how people affect the environment. Therefore, we selected days of air quality above grade II as a state variable in this subsystem, and simulated the interactive relationship between days of air quality above grade II and carbon dioxide emissions, sulfur dioxide emissions, annual average daily particulate matter, annual rainfall, or social attention. Directly or indirectly, once the air quality is influenced by particulate matter, carbon dioxide, and sulfur dioxide emitted during industrial production, people will pay more attention to the environment, thereby taking measures to control the emissions of pollutants with the goal of improving air quality. Figure 5 shows the environment subsystem flowchart.

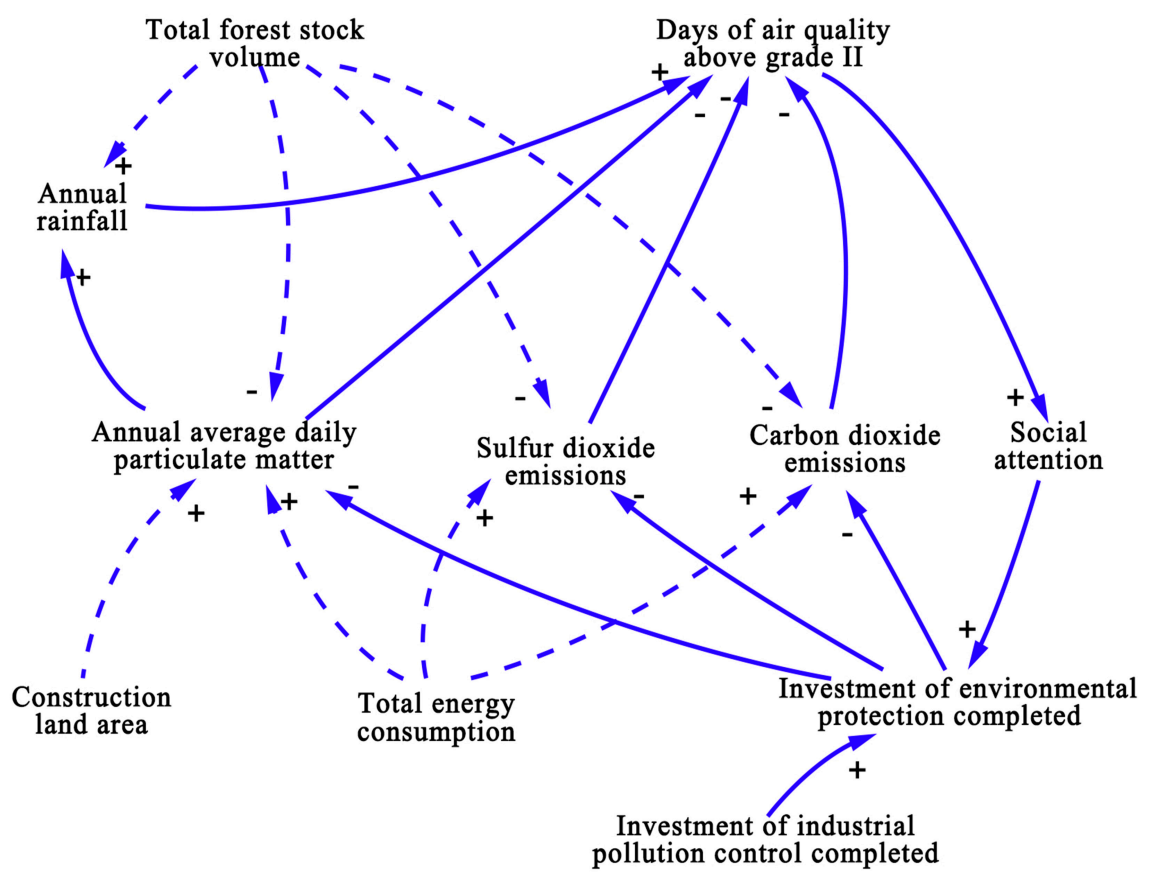

Figure 5. Flowchart of system dynamics of the environment subsystem of Beijing. 
Causal feedback relationships:

(1) Days of air quality above grade $\mathrm{II} \rightarrow+$ social attention $\rightarrow+$ investment of environmental protection completed $\rightarrow-\mathrm{SO}_{2}$ emissions $\rightarrow$ - days of air quality above grade II

(2) Days of air quality above grade $\mathrm{II} \rightarrow+$ social attention $\rightarrow+$ investment of environmental protection completed $\rightarrow-\mathrm{CO}_{2}$ emissions $\rightarrow$ - days of air quality above grade II

(3) Days of air quality above grade $\mathrm{II} \rightarrow+$ social attention $\rightarrow+$ investment of environmental protection completed $\rightarrow+$ annual average daily particulate matter $\rightarrow-$ annual rainfall $\rightarrow+$ days of air quality above grade II

(4) Days of air quality above grade $\mathrm{II} \rightarrow+$ social attention $\rightarrow+$ investment of environmental protection completed $\rightarrow+$ annual average daily particulate matter $\rightarrow$ - days of air quality above grade II

Equations expressing the environment subsystem are available as Appendix C.

\subsubsection{Testing the Effectiveness of the Model}

To verify the degree of error among the simulated and actual values in the model, this paper used the historical data from 2000 to 2010 to simulate the main variables from 2011 to 2013, taking 2000 as the base year and using a time step of one year. The relative error was calculated by contrasting the simulated and actual values. We selected three state variables of subsystems as test variables: (a) year-end population; (b) total forest stock volume; and (c) days of air quality above grade II. The results indicated that the average relative error was $2.6 \%$ in the model, peaking at $6.6 \%$, with less than $10 \%$ model error, which was within the allowable range (Figures $6 \mathrm{a}-\mathrm{c}$ ). Therefore, the simulation time from 2014 to 2020 for FES in Beijing was reasonable.

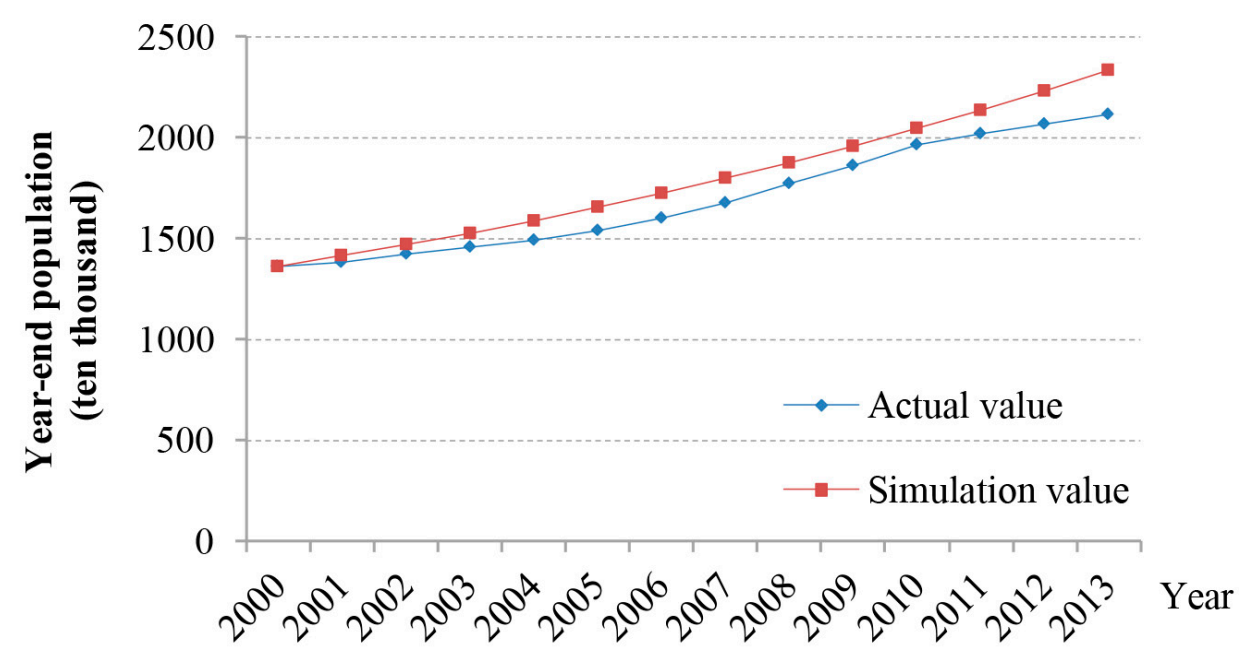

(a)

Figure 6. Cont. 


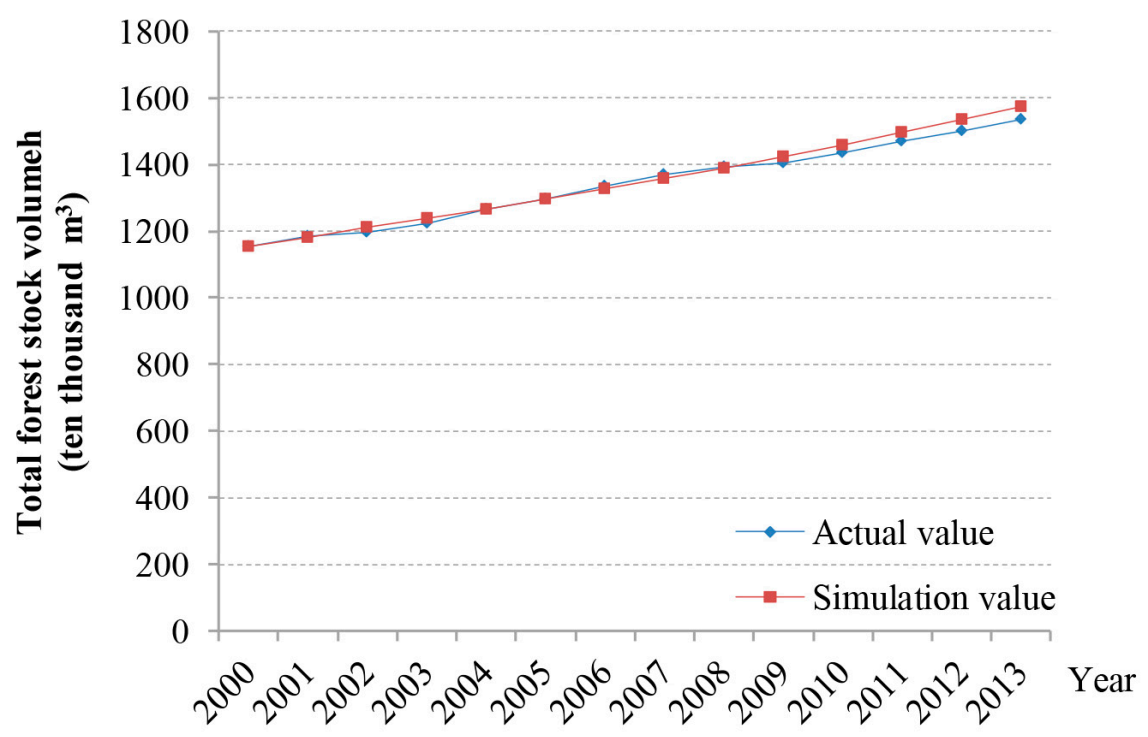

(b)

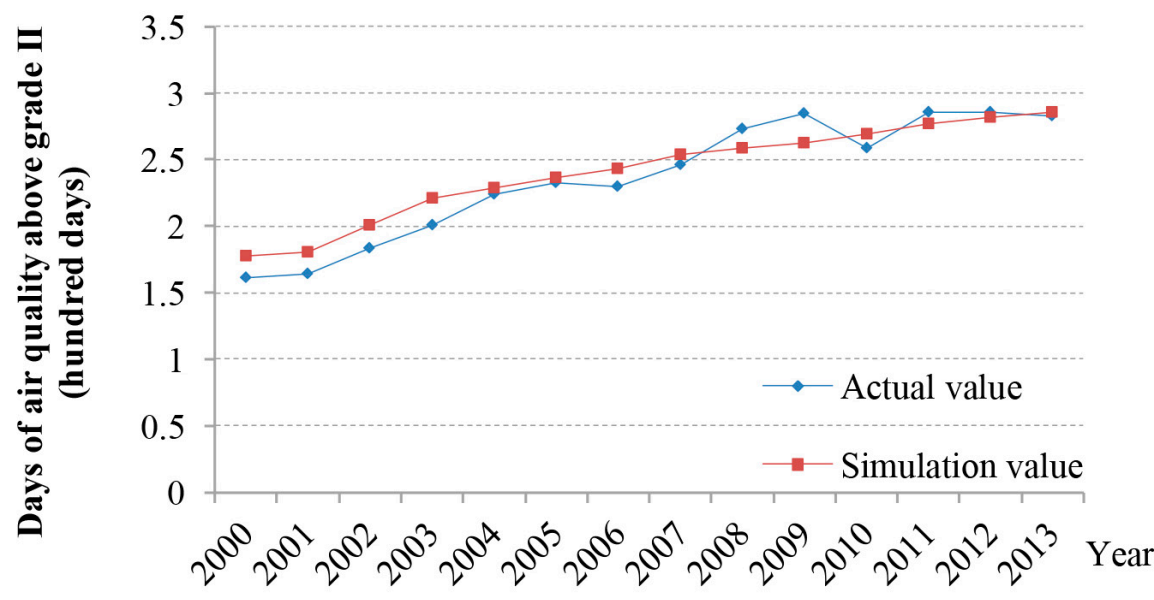

(c)

Figure 6. Error testing based on (a) the year-end population, (b) the total forest stock volume and (c) the days of air quality above grade II in Beijing for 2000-2013.

\subsection{Design of Dynamic Control Scenarios}

Numerous scenarios can be applied to the SSOCM. However, to facilitate the coordinated development of FES while improving the social economy and environment in Beijing, we proposed four dynamic control scenarios that are relevant to Beijing's current situation: (a) medium-speed socioeconomic development, (b) strengthening environmental management, (c) developing reasonable forest management policies and (d) a scenario combining all three by coordinating forest resource management, the social economy, and other environmental issues (Table 2). Scenarios were developed by manipulating the relevant parameters to reflect the effects of certain situations on the FES performance. Based on the causal feedback in Figure 2, parameters in the intersection of subsystem models which could regulate the entire system were selected as control parameters to simulate the four proposed scenarios. The parameters' value settings are entirely dependent on forestry, socioeconomic and environmental development policies, and plans in Beijing. 
Table 2. Forecast scenarios for forest ecological security in Beijing.

\begin{tabular}{|c|c|c|}
\hline Scenario & Key Strategies & Detailed Procedure \\
\hline Scenario 0 & Initial state & $\begin{array}{l}\text { Maintain current socioeconomic, environment and forest } \\
\text { resource development trend, and regard this as the reference } \\
\text { for the other } 4 \text { scenarios. }\end{array}$ \\
\hline Scenario 1 & $\begin{array}{c}\text { Medium-speed } \\
\text { socioeconomic } \\
\text { development }\end{array}$ & $\begin{array}{l}\text { (1) Propose macroeconomic regulation to control economic growth } \\
\text { rate. Set the GDP growth rate to } 7 \% \text {. (2) Reduce population growth } \\
\text { rate to below } 3.5 \% \text { by controlling migrants to alleviating pressure } \\
\text { on FES caused by population growth. }\end{array}$ \\
\hline Scenario 2 & $\begin{array}{l}\text { Strengthening } \\
\text { environmental } \\
\text { management }\end{array}$ & $\begin{array}{l}\text { Reduce carbon dioxide (an annual decrease of } 1.115 \times 10^{7} \text { tons) and } \\
\text { sulfur dioxide emissions (an annual decrease of } 2.0 \times 10^{4} \text { tons) as } \\
\text { well as reducing annual average daily particulate matter (an annual } \\
\text { decrease of } 5 \mathrm{mg} / \mathrm{m}^{3} \text { ) by the implementation of environmental } \\
\text { control measures to increase investment of environmental protection, } \\
\text { ensuring innovation of environmental protection technology. }\end{array}$ \\
\hline Scenario 3 & $\begin{array}{l}\text { Developing } \\
\text { reasonable forest } \\
\text { management policies }\end{array}$ & $\begin{array}{l}\text { Implement forest policy to encourage the Beijing government to } \\
\text { increase investment in forest resources. (1) Enhance forestry } \\
\text { investment increased by an annual of } 3 \text { billion Yuan, aiming to } \\
\text { promote the forestation; (2) Implement the Limitation of Forest } \\
\text { Deforestation Policy to force the reduction of forest harvesting } \\
\text { to a quota of } 8.0 \times 10^{4} \mathrm{~m}^{3} \text { annually }\end{array}$ \\
\hline Scenario 4 & $\begin{array}{l}\text { Combining all three } \\
\text { by coordinating forest } \\
\text { resource } \\
\text { management, the } \\
\text { social economy, } \\
\text { and other } \\
\text { environmental issues }\end{array}$ & $\begin{array}{l}\text { Incorporate Scenarios 1-3. Update the structure of socioeconomic } \\
\text { development and achieve the overall development of urban and } \\
\text { rural areas; Maintain technological innovation and improve } \\
\text { environmental quality Enhance the forestry attention and lead } \\
\text { FES to a sustainable development }\end{array}$ \\
\hline
\end{tabular}

\subsubsection{Scenario 1-Medium-Speed Socioeconomic Development}

Scenario 1 aims to simulate the control of both population and economic growth with the goal of alleviating pressure on FES by slowing economic growth and controlling immigration into Beijing.

(a) Macroeconomic regulation is proposed to ensure the steady growth of the regional economy in Beijing. However, the economic growth rate needs to be controlled to a certain degree to alleviate any negative effects caused by economic development. In the period of strategic opportunities, the national government proposed a normal rate of new economic development, which was a mid-range rate of growth of $7 \%-8 \%$ annually [80]. Therefore, in Scenario 1, the GDP growth rate is set to decline to $7 \%$.

(b) An increasing number of immigrants are attracted to Beijing because of the abundant employment opportunities. Population aggregation has a negative effect on forest resource consumption. Therefore, in Scenario 1, immigrants to Beijing are controlled by adjusting the household registration policy to reduce population growth to below $3.5 \%$ annually, and to alleviate the consequent pressure on FES. 


\subsubsection{Scenario 2-Strengthening Environmental Management}

Scenario 2 implemented environmental regulations and control measures to provide a stable environment for the forest ecosystem, aiming to reduce carbon dioxide and sulfur dioxide emissions as well as reducing the concentration of annual average daily particulate matter. Beijing has developed rapidly with the expansion of global urbanization. The carbon dioxide and sulfur dioxide emissions have risen annually because of the development of secondary industries in Beijing. Rapid development of the transportation industry made the situation worse; car ownership was high with $5.47 \times 10^{6}$ cars in Beijing in 2014 [39]. Considering the above issues, Scenario 2 simulates the encouragement of local government and enterprises to increase investment in environmental protection through the implementation of environmental regulations and control measures, ensuring innovation of environmental protection technology and promoting social attention to the environment. Based on the environmental index provided by the Beijing Municipal Environmental Protection Bureau and Municipal Commission Development and Reform, the Government of Beijing proposed the goal of decreasing carbon dioxide emissions by $2.5 \%$ per year and the average daily particulate matter index by $5 \%$ per year in the Report on the Work of the Government [81]. Therefore, Scenario 2 sets the parameters as follows: reducing carbon dioxide emissions by $1.115 \times 10^{7}$ tons per year; limiting average daily particulate matter and sulfur dioxide emissions by $5 \mathrm{mg} / \mathrm{m}^{3}$ per year; and $2.0 \times 10^{4}$ tons per year, respectively.

\subsubsection{Scenario 3-Developing Reasonable Forest Management Policies}

Based on the the long-term goal proposed by Beijing Forestry Development Strategy, Scenario 3 emphasizes the implementation of forest policy control measures which aim to increase investment in forest resources and to control harvesting [82]. Scenario 3 encourages the Beijing government to enhance forestry investment and increasing it by three billion Yuan annually, aiming to promote afforestation in each district and county. In addition, this scenario implements the Limitation of Forest Deforestation Policy to control illegal logging and deforestation and force the reduction of forest harvesting to a quota of $8.0 \times 10^{4} \mathrm{~m}^{3}$ annually.

\subsubsection{Scenario 4-Combining All Three by Coordinating Forest Resource Management, the Social} Economy, and Other Environmental Issues

Scenario 4 incorporates Scenario 1-3, and implements a comprehensive development plan of reducing the growth rate in GDP to 7\%, maintaining a population growth rate below $3.5 \%$, as well as limiting carbon dioxide, sulfur dioxide and particulate matter emissions to $1.115 \times 10^{7}$ tons per year, $2.0 \times 10^{4}$ tons per year and annual average daily particulate matter $5 \mathrm{mg} / \mathrm{m}^{3}$ per year, respectively. In addition, Scenario 4 calls for reducing the forest harvesting quota by an additional $8.0 \times 10^{4} \mathrm{~m}^{3}$ every year and increasing forestry investment by three billion Yuan annually.

\section{Results}

Based on the proposed scenarios, the development trends of FES were assessed using the SD model and the FES index value. A reasonable method of coordinated development could then be selected 
based on the simulation results. Forest resources provide the foundation of supporting a forest ecosystem. Providing abundant forest resources is a main focus in promoting the ability of the forest to resist external pressures and assure regional FES. Meanwhile, total forest stock volume and forest stock volume per unit land area or forest coverage rate are important parameters that can be used to measure the quality and quantity of forest resources. Therefore, these parameters were simulated for comparative analysis.

\subsection{Performance for the Three Key Stocks}

In the following section, the performance of three key stocks is analyzed. Figure 7 presents the simulation results.

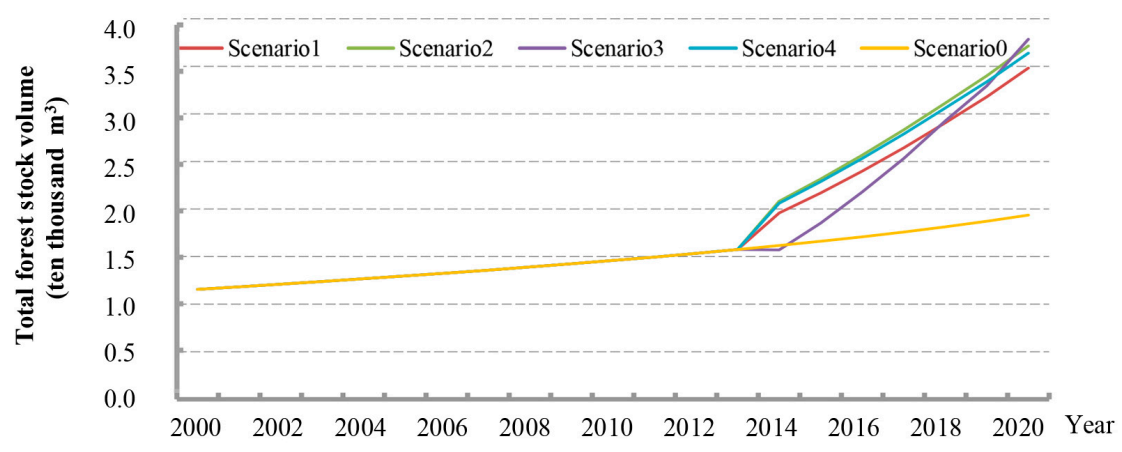

(a)

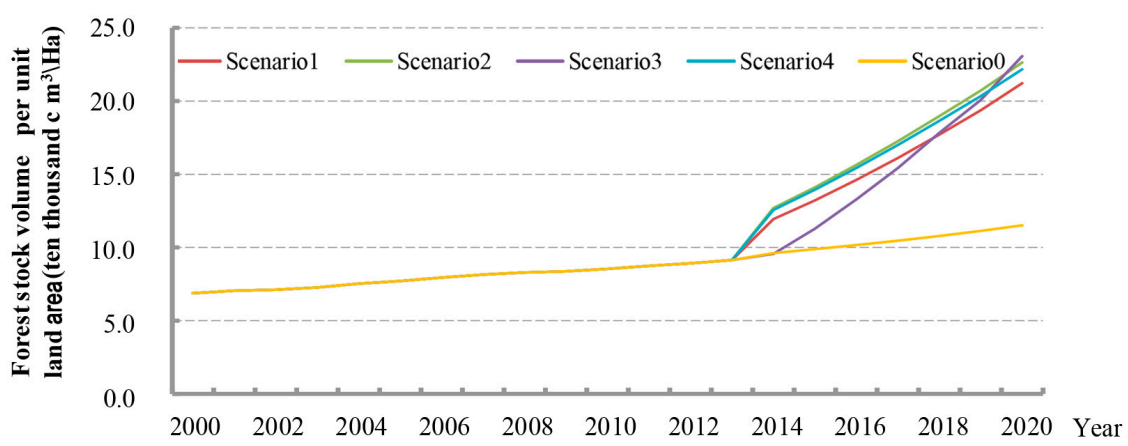

(b)

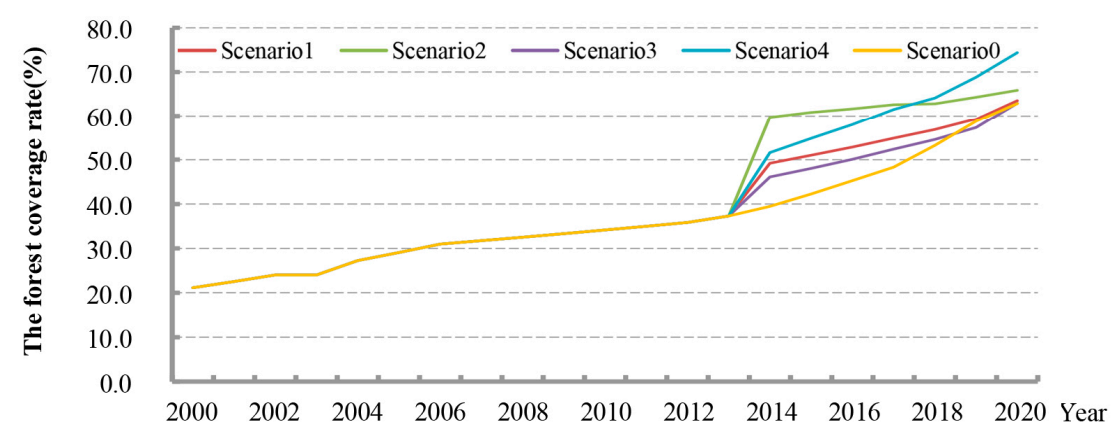

(c)

Figure 7. Development trend for: (a) the total forest stock volume; (b) the forest stock volume per unit of forest land; and (c) the forest coverage rate with different scenarios for Beijing for 2000-2020. 
According to the simulation, the total forest stock volume increased together with forest stock volume per unit land area. The performance of the total forest stock volume and forest stock volume per unit land area are projected to exhibit a continuous increasing trend from 2000 to 2020 in every scenario. The total forest stock volume and forest stock volume per unit land area in Scenarios 1, 2, 3 and 4 were higher than Scenario 0 by 2020. The designed scenarios were determined to affect the improvement of forest stock volume. Of these, Scenario 3 would represent the greatest improvement. In Scenario 3, the total forest stock volume will reach $3.78 \times 10^{7} \mathrm{~m}^{3}$ by 2020 compared with $1.93 \times 10^{6}$ $\mathrm{m}^{3}$ in Scenario 0 (Figure 7a); forest stock volume per unit land area will rise to $2.306 \times 10^{5} \mathrm{~m}^{3} / \mathrm{ha}$ compared with $1.152 \times 10^{5} \mathrm{~m}^{3} /$ ha in Scenario 0 (Figure $7 \mathrm{~b}$ ). The total forest stock volume and forest stock volume per unit land area exhibited the highest improvement under the forest policy control when compared to other scenarios. Obviously managing forest policies is the most effective way to promote the forest stock volume. According to Figure 7c, Scenarios 1, 2 and 3 would slightly enhance the performance of the forest coverage over a long-term period. Scenario 4 influences the forest coverage greatly. The forest coverage will reach $74.3 \%$ by 2020 compared with $21.1 \%$ in the base year in Scenario 4. Combining all three scenarios by coordinating forest resource management, the social economy, and other environmental issues is the best way to improve the forest coverage.

\subsection{Performance for the FES}

Figure 8 presents the overall performance of FES in Beijing. All the scenarios in 2020 will provide better conditions than in 2000. From these results, it can be determined that designed scenarios all effectively improve the FES in Beijing.

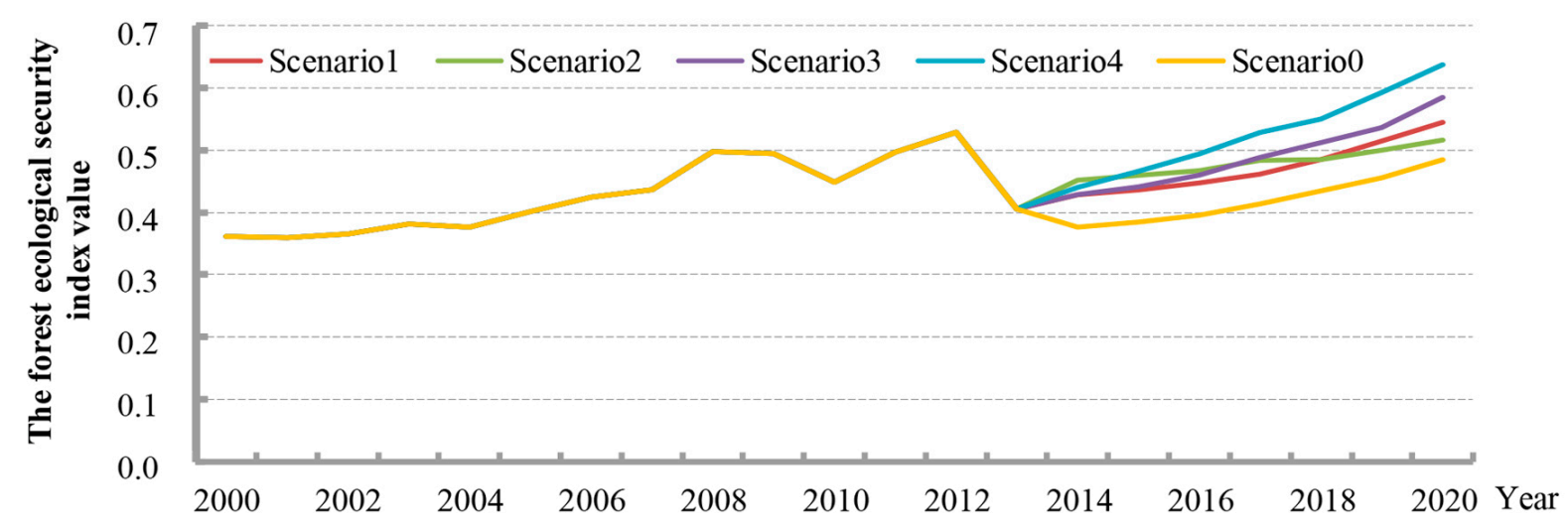

Figure 8. Development trend for the forest ecological security index value with different scenarios for Beijing for 2000-2020.

The FES index value in Scenario 0 exhibited a fluctuating and increasing trend, which reached the best state (FES index value 0.5741) in 2012 during the study period; however, it deteriorated in 2014 (FES index value 0.4124 ), while improving slightly after 2015 (Figure 8).

In Scenario 1, the FES index value increased to a certain degree compared with Scenario 0 (Figure 8). The FES index value in Scenario 1 will reach 0.545 by 2020 compared with 0.485 in Scenario 0. The reason why the FES index increases in Scenario 1 is that a slowdown of economic growth and alleviation of population pressure resulted in an improved FES. However, forestry 
investment would be reduced accordingly because of the slowdown in the economy. Meanwhile, environment and forest policy control are ignored in this scenario. As a result, the overall improvement of the FES index under socioeconomic control is not obvious.

By 2020, the FES index in Scenario 2 exhibits no obvious change (Figure 8). The main reason is that socioeconomic control and forest policy control are ignored in Scenario 2.

In Scenario 3, up to 2020, the FES index value will increase to 0.585 , obviously higher than 0.485

in Scenario 0 (Figure 8), which indicates that the increased investment in forestry resources and reduction in the forest harvesting quota are important ways to promote FES in the long term.

In Scenario 4, the FES index value reached 0.637 in 2020, which was higher than $0.485,0.545$, 0.516 and 0.585 in Scenarios 0, 1, 2 and 3, respectively (Figure 8). This scenario indicates that the FES index value will exhibit the greatest improvement when it is under comprehensive control.

\section{Discussion}

The historical trends of the FES index value exhibited an increasing trend from 2000 to 2012, but declined in 2013. The main reasons are as follows: (i) In 2000, the State Forestry Bureau in China established six major forestry projects [83]. Consequently, the investment in forestry in Beijing expanded rapidly with the backing of the Beijing government and peaked at $2.49 \times 10^{4}$ Yuan per ha, which guaranteed the development of ecologically sound habitat protection work in Beijing [38]. In addition, with investment backing, the afforestation area reached $3.19 \times 10^{5}$ ha from 2000 to 2012 and the forest coverage increased annually [37]. A fume discharge problem was resolved when the Capital Steel Plant (CS) was relocated in 2008. Thus, the quality of the environment improved markedly. Overall, the FES index value exhibited an increasing trend from 2000 to 2012 in Beijing. (ii) The GDP per unit of forestland rose in 2013 [37]. Thus, the harvest and consumption of forest resources and occupation of previously forested land surged because of rapid economic growth. Moreover, the sulfur dioxide and carbon dioxide emissions index increased rapidly in 2013 [38,40], which led to a decrease in environmental quality. Therefore, the FES index value tumbled in 2013.

The simulation results of the FES index value (Scenarios 0-4) from 2014 to 2020 indicate that FES in Beijing is positively affected by improving forest management policies, improving the state of forest resources, managing socioeconomic development and actively improving environmental management techniques. In the future, the stability and health of the forest environment can only be safeguarded when the productivity and sustainable activity of forest resource management is actively maintained, and orderly socioeconomic development is taken into consideration. This will allow the dynamic and cooperative development of the internal and external forest resource-social, economy-environment, compound system to be realized and the FES in Beijing to be comprehensively improved.

During the periods of the 12th and 13th 5-Year Plans in China, the national government should seize the opportunity to initiate a new round of forest development, formulate scientific and reasonable forestry policies and accelerate forestry development based on the results of the FES issues in the 12th 5-year period. Also, the Beijing government and related forestry organizations should enhance the development of forest resources, alleviate the pressure on FES caused by the increase in population, and strengthen cooperation with related environmental organizations, thus improving the forest environment through technological innovation. In addition, the development of agencies designed to 
assess ecological security and the related ecological protection mechanisms should be strengthened. An FES and a real-time monitoring platform should be established to more effectively obtain forest-related ecological data. Furthermore, Statistical Yearbook data related to early warning simulations should be established for continuous and in depth forecasting and scenario simulation for FES in Beijing.

\section{Conclusions}

This paper defined the concept of FES and established a system dynamics model for the analysis of scenarios and a control model of FES to generate and select the most reasonable and effective control model for FES in Beijing. Accordingly, a sustainable development mode in support of FES in Beijing is summarized. The main conclusions follow:

(i) The initial FES index value (in Scenario 0) increased to its highest level of 0.529 in 2012, but declined slightly to 0.485 by 2020 .

(ii) In Scenarios 1-3, the FES levels are respectively enhanced in varying degrees when compared with Scenario 0; however, these scenarios cannot meet the requirements for sustainable development of FES in Beijing. Only when forest policy, socioeconomic and environment control (Scenario 4) are simultaneously executed for some time, could the FES in Beijing be significantly improved.

(iii) The improvement of forest management policies, socioeconomic development and environmental management comprehensively affected FES in Beijing. The optimal mode involves maintaining forest productivity and managing forest resources sustainably, guarding the stability and health of the forest environment and taking the concept of orderly socioeconomic development into consideration.

(iv) Because limited data was available, data from 2000 to 2013 were used to forecast the FES in Beijing from 2014 to 2020 . The FES index system needs further improvement. If the forecast period can be extended, the effects will have greater macro-control significance. In addition, this paper evaluated and forecasted FES in a temporal dimension. Comparative analysis of evaluating and forecasting FES in different counties within Beijing in a spatial-temporal dimension will become an important topic of future research.

\section{Acknowledgments}

The authors are indebted to the Major Program of the Fundamental Research Funds for the Central Universities in China (Grant No. BLYJ201502), the Humanities and Social Sciences Foundation of the Ministry of Education (No. 14YJCZH106) and the 12th National Five-year Science and Technology Support Project (No. 2012BAJ24B05). The insightful and constructive comments of editors and two anonymous reviewers are greatly appreciated.

\section{Author Contributions}

Shasha Lu and Fangzheng Li contributed to the development of the idea and participated in all phases. Xiong Li and Benye Xi helped perform the analysis with constructive discussion. Yinan Sun 
and Weiqi Liu helped improve the figures and manuscript. All authors have read and approved the final manuscript.

\section{Conflicts of Interest}

The authors declare no conflict of interest.

\section{Appendix A}

(1) total forest stock volume (TFSV): L TFSV = INTEG (FSVAI.JK - FSC.JK, 1.1552)

(2) forest stock volume annual increment (FSVAI): R FSVAI.KL $=0.011 \times$ AF.K $+0.040 \times$ TFA.K + MFR $\times$ TFSV.K

(3) forest stock consumption (FSC): R FSC.KL = FHQ.K + (TFSV/TFA) $\times$ TFA.K

(4) total forest area (TFA): L TFA.K $=$ DT $\times($ PWFA.JK + CFA.JK)

(5) forest park area (FPA): A FPA.KL $=$ SAT $\times$ FCI.K

(6) commodity forest area (CFA): R CFA.KL = TFA.K - PWFA.K

(7) public welfare forest area (PWFA): L PWFA.JK = PWFA.JK + DT $\times$ FPA.JK

(8) forest harvesting quota (FHQ): R FHQ.KL $=\mathrm{WCPUG} \times \mathrm{PIO} . \mathrm{K}+\mathrm{MFR} \times \mathrm{TFSV} . \mathrm{K}$

(9) investment in forest resources $(\mathrm{FCI})$ : A FCI.KL $=$ FCII $\times$ SAT $\times$ GDP.K

Where TFSV is total forest stock volume, FDA is forest disaster area, FHA is forest harvesting quota, FCI is investment in forest resources, FPA is forest park area, PWFA is public welfare forest area, CFA is commodity forest area, TFA is total forest area, MFR is mature forest rate, SAT is social attention, FPAI is forest park area increment, FCII is investment in forest resources index and WCPUG is wood consumption per unit GDP.

\section{Appendix B}

(1) population (POP): L POP.K = INTEG (NPPY.JK, 1.3636)

(2) net population per year (NPPY): R NPPY.KL = IPOP.K - EPOP.K

(3) GDP: A GDP.KL=GPA.K $\times$ POP.K

(4) total energy consumption $(\mathrm{TEC})$ : A TEC.KL $=\mathrm{ECPC} \times \mathrm{POP} . \mathrm{K}+\mathrm{ECPUG} \times(\mathrm{PIO}+\mathrm{SIO}) . \mathrm{K}$

(5) construction land area $(\mathrm{CLA}): \mathrm{A}$ CLA.KL $=$ OAPUG1 $\times$ PIO.K + OAPUG $2 \times$ SIO.K + OAPUG $3 \times$ TIO.K

(6) tertiary industry output (TIO): A TIO.KL $=$ ISI $\times$ POP $\times$ GPC.K

(7) secondary industry output (SIO): A SIO.KL $=$ ISI $\times$ POP $\times$ GPC.K

(8) primary industry output $(\mathrm{PIO})$ : A PIO.KL $=\mathrm{ISI} \times \mathrm{POP} \times \mathrm{GPC} . \mathrm{K}$

(9) investment of industrial pollution control completed (IIPCC): A IIPCC.KL = PCPUG $\times$ (PIO.K + SIO.K)

(10) investment of environmental protection completed (IEPC): A IEPC.KL $=0.014 \times$ IIPCC.K

(11) GDP per capita (GPC): T GPC = WITH LOOKUP (Time, ([(2000, 0) - (2020, 20)], (2000, 2.4127), (2001, 2.698), (2002, 3.073), (2003, 3.4777), (2004, 4.0916), (2005, 4.5993), (2006, 5.1722), (2007, 6.0096), (2008, 6.4491), (2009, 6.694), (2010, 7.3856), (2011, 8.1658), (2012, 
8.7475), (2013, 9.3213), (2014, 9.724), (2015, 9.84912), (2016, 10.137), (2017, 10.3877), $(2018,10.26),(2019,10.7018),(2020,11.1404)))$

Where TPOP is total population, PIO is primary industry output, SIO is secondary industry output, TIO is tertiary industry output, CLA is economic benefits by occupying land, TEC is total energy consumption, GPC is GDP per capita, OAPUG is occupied area per unit GDP, POPUG is pollution output per unit GDP, ISI is industrial structure index, ECPC is energy consumption per capita, ECPUG is energy consumption per unit GDP, PCPUG is pollution control per unit GDP, PERPUG is pollution control per unit GDP, IPOP is immigration population and EPOP is emigration population.

\section{Appendix C}

(1) days of air quality above grade II (DAQAG): L DAQAG.K = DAQAG.JK + DT × (-COE.JK SOE.JK - AADPM.JK)

(2) $\mathrm{CO}_{2}$ emissions $(\mathrm{COE}): \mathrm{R}$ COE.KL $=\mathrm{COA} \times \mathrm{TFSV} . \mathrm{K}+\mathrm{ECBR} \times \mathrm{TEC} . \mathrm{K}+\mathrm{GOE} \times \mathrm{IEPC} . \mathrm{K}$

(3) $\mathrm{SO}_{2}$ emissions $(\mathrm{SOE}): \mathrm{R} \mathrm{SOE} . \mathrm{KL}=\mathrm{SOA} \times \mathrm{T}$ FSV.K $+\mathrm{ECBR} \times \mathrm{TEC} . \mathrm{K}+\mathrm{GOE} \times \mathrm{IEPC} . \mathrm{K}$

(4) annual rainfall (AR): R AR.KL $=$ IFR $\times($ TFSV.K + AADPM.K)

(5) annual average daily particulate matter (AADPM): A AADPM.KL $=$ DPR $\times$ CLA.K + DUA $\times$ TFSV.K + $(1-$ ECBR $) \times$ TEC.K

(6) investment of environmental protection completed (IEPC): A IEPC.KL $=0.014 \times$ IIPCC.K

Where DAQAG is days of air quality above grade II, COE is carbon dioxide emissions, SOE is sulfur dioxide emissions, AADPM is annual average daily particulate matter, AR is annual rainfall, SAT is social attention, $\mathrm{COA}$ is $\mathrm{CO}_{2}$ absorptivity, ECBR is energy complete burning rate, GOE is governance efficiency, $\mathrm{SOA}$ is $\mathrm{SO}_{2}$ absorptivity, DPR is dust production rate, DUA is dust absorptivity, IFR is impact factor of rainfall and TEC is total energy consumption.

\section{References}

1. Dai, F.Q.; Nan, L.; Liu, G.C. Assessment of regional ecological security based on ecological footprint and influential factors analysis: A case study of Chongqing Municipality, China. Int. J. Sustain. Dev. World Ecol. 2010, 17, 390-400.

2. Li, X.B.; Tian, M.R.; Wang, H.; Wang, H.; Yu, J.J. Development of an ecological security evaluation method based on the ecological footprint and application to a typical steppe region in China. Ecol. Indic. 2014, 39, 153-159.

3. Zhang, S.H.; Wang, S.R.; Wang, Y.M. Impacts of climate disaster on Beijing's sustainable development and relevant strategies. Acta Geogr. Sin. 2000, 55, 119-127.

4. Xue, P.P.; Wang, B.; Niu, X. A simplified method for assessing forest health, with application to Chinese fir plantations in Dagang Mountain, Jiangxi, China. J. Food Agr. Environ. 2013, 11, 1232-1238.

5. Allen, C.D. Climate induced forest dieback: An escalating global phenomenon. Unasylva 2009, 60, 43-49. 
6. Ferretti, M.; Konig, N.; Rautio, P.; Sase, H. Quality assurance (QA) in international forest monitoring programmes: Activity, problems and perspectives from East Asia and Europe. Ann. For. Sci. 2009, 66, 403-414.

7. Fang, J.; Lu, S.W.; Yu, X.X.; Rao, L.Y.; Xie, Y.Y.; Zhang, Z.M. Forest ecosystem service and its evaluation in China. Chin. J. Appl. Ecol. 2005, 8, 1531-1536.

8. Oszlanyi, J. Forest health and environmental pollution in Slovakia. Environ. Poll. 1997, 98, 389-392.

9. Szepesi, A. Forest health status in Hungary. Environ. Poll. 1997, 98, 393-398.

10. Opinions on Promoting the Development of an Ecologically-Sound Civilization; CPC Central Committee: Beijing, China, 2015.

11. Wang, H.; Long, H.L.; Li, X.B.; Yu, F. Evaluation of changes in ecological security in China's Qinghai lake basin from 2000 to 2013 and the relationship to land use and climate change. Environ. Earth Sci. 2014, 72, 341-354.

12. Xiao, D.N. Ecological Security and Ecological Build, 1st ed.; China Meteorological Press: Beijing, China, 2002; pp. 23-27.

13. Shao, C.F.; Tian, X,G.; Guan, Y.; Ju, M.T.; Xie, Q. Development and application of a new grey dynamic hierarchy analysis system (GDHAS) for evaluating urban ecological security. Int. J. Environ. Res. Public Health 2013, 10, 2084-2108.

14. Zhao, X.Q.; Xu, X.H. Research on landscape ecological security pattern in a eucalyptus introduced region based on biodiversity conservation. Russ. J. Ecol. 2015, 46, 59-70.

15. Xu, L.Y.; Yin, H.; Li, Z.X.; Li, S. Land ecological security evaluation of Guangzhou, China. Int. J. Environ. Res. Public Health. 2014, 11, 10537-10558.

16. Zhang, J.Y.; Wang, L.C. Assessment of water resource security in Chongqing city of China: What has been done and what remains to be done? Nat. Hazards 2015, 75, 2751-2772.

17. Xu, J.L.; Ding, Y. Research on early warning of food security using a system dynamics model: Evidence from Jiangsu province in China. J. Food. Sci. 2015, 80, R1-R9.

18. Zhang, Z.; Lu, W,X.; Zhao, Y.; Song, W.B. Development tendency analysis and evaluation of the water ecological carrying capacity in the Siping area of Jilin Province in China based on system dynamics and analytic hierarchy process. Ecol. Model. 2014, 275, 9-21.

19. Li, Y.C.; He, C.Y. Scenario simulation and forecast of land use/cover in northern China. Chin. Sci. Bull. 2008, 53, 1401-1412.

20. Chen, H.; Chang, Y.C.; Chen, K. Integrated wetland management: An analysis with group model building based on system dynamics model. J. Environ. Manag. 2014, 146,309-319.

21. Chen, M.C.; Chang, K.W. Reasoning the causality of city sprawl, traffic congestion, and green land disappearance in Taiwan using the CLD model. Int. J. Environ. Res. Public Health 2014, 11, 11464-11480.

22. Schaeffer, D.J.; Cox, D.K. Establishing Ecosystem Threshold Criteria; Island Press: Washinton, DC, USA, 1992.

23. Das, M.; Kumar, A.; Mohapatra, M.; Muduli, S.D. Evaluation of drinking quality of groundwater through multivariate techniques in urban area. Environ. Monit. Assess. 2010, 166, 149-157.

24. Gau, H.S.; Hsieh, C.Y.; Liu, C.W. Application of grey correlation method to evaluate potential groundwater recharge sites. Stoch. Environ. Res. Risk Assess. 2006, 20, 407-421. 
25. Lundquist, J.E. Use of fourier transforms to define landscape scales of analysis for disturbances: A case study of thinned and un thinned forest stands. Landsc. Ecol. 2002, 17, 445-454.

26. Wackernagel, M. The ecological footprint: an indicator of progress toward regional sustainability. Environ. Monit. Assess. 1998, 51, 511-529.

27. Bartel, A. Analysis of landscape pattern: towards a "top-down" indicator for evaluation of land use. Ecol. Model. 2000, 130, 87-94.

28. Onkal-Engin, G.; Demir, I.; Hiz, H. Assessment of urban air quality in Istanbul using fuzzy synthetic evaluation. Atmos. Environ. 2004, 38, 3809-3815.

29. Chen, K.P. Artificial neural networks for risk decision support in natural hazards: A case study of assessing the probability of house survival from bushfires. Environ. Model. Assess. 2004, 9, 189-199.

30. Yim, N.H.; Kim, S.H.; Kim, H.W. Knowledge based decision making on higher level strategic concern system dynamics approach. Expert. Syst. Appl. 2004, 27, 143-158.

31. Forrester, J.W. Industrial dynamics; MIT Press: Cambridge, UK, 1961.

32. Egilmez, G.; Kucukvar, M.; Tatari, O. Sustainability assessment of U.S. manufacturing sectors: An economic input output-based frontier approach. J. Clean. Prod. 2013, 53, 91-102.

33. Casey, R.; Töyli, J. Mobile voice diffusion and service competition: A system dynamic analysis of regulatory policy. Telecommun. Policy 2012, 36, 162-174.

34. Liao, Z.X.; Jin, M.Z.; Ren, P.Y.; Luo, Y.Y. Research on Scenic Spot's Sustainable Development Based on a SD Model: A Case Study of the Jiuzhai Valley. Sustainability 2014, 6, 4632-4644.

35. Wang, H.H.; Li, M.R.; Hu, N.P.; Gao, Y.M. Utilization effectiveness of marine functional zones using system dynamics for China: Modeling and assessment: A case study of Qingdao Mariculture Functional Zones. J. Coast. Conserv. 2014, 18, 609-616.

36. Xie, G.D.; Li, W.H.; Xiao, Y.; Zhang, B.; Lu, C.X.; An, K.; Wang, J.X.; Xu, K.; Wang, J.Z. Forest ecosystem services and their values in Beijing China. Geogr. Sci. 2010, 20, 51-58.

37. Yu, X.Q.; Xu, S.J.; Li, X.M. The Beijing Area Statistical Yearbook (2000-2013); Beijing Municipal Bureau of Statistics: Beijing, China, 2000-2013.

38. Jia, Z.B.; Zhang, J.L. Forest Resources Report of China-The Seventh Forest Resources Inventory; The State Forestry Administration of The People's Republic of China: Beijing, China, 2009.

39. Xia, Q.F. The Beijing Statistical Yearbook (2014); Beijing Municipal Bureau of Statistics: Beijing, China, 2014.

40. Smith, W.H. Air pollution-Effects on the structure and function of the temperate forest ecosystem. Environ. Pollut. 1970, 6, 111-129.

41. Chen, Y.Y.; Jin, G.Z.; Kumar, N.; Shi, G. The promise of Beijing: Evaluating the impact of the 2008 Olympic Games on air quality. J. Environ. Econ. Manag. 2013, 66, 424-443.

42. Indicators for National Forest City; The State Forestry Administration of The People's Republic of China: Beijing, China, 2007.

43. Yao, N.; Ma, L.Y.; Yang, J.; Jia, L.M.; Duan, J.; Huang, C.H. Changes of ecological spaces in Beijing's plain areas between 1992 and 2013. Chin. J. Ecol. 2015, 34, 1427-1434. (In Chinese)

44. Hodson, M.; Marvin, S. 'Urban ecological security': A new urban paradigm? Int. J. Urban Reg. Res. 2009, 33, 193-215.

45. Yang, J.; Dai, G.H.; Wang, S.R. China's national monitoring program on ecological functions of forests: An analysis of the protocol and initial results. Forests 2015, 6, 809-826. 
46. Perles, S.J.; Wagner, T.; Irwin, B.J.; Manning, D.R.; Callahan, K.K.; Marshall, M.R. Evaluation of a regional monitoring program's statistical power to detect temporal trends in forest health indicators. Environ. Manag. 2014, 54, 641-655.

47. Tkacz, B.; Moody, B.; Castillo, J.V. Forest health conditions in North America. Environ. Pollut. 2008, 155, 409-425.

48. Shrader-Frechette, K.S. Ecosystem health: A new paradigm for ecological assessment. Trends Ecol. Evol. 1994, 9, 456-457.

49. Vora, R.S. Developing programs to monitor ecosystem health and effectiveness of management practices on Lakes States National Forests, USA. Biol. Conserv. 1997, 80, 289-302.

50. Mark, J.A.; Barbara, L.C. Forest Health Monitoring: 2006 National Technical Report; Southern Research Station: Asheville, NC, USA, 2009.

51. Oswalt, S.N.; Campbell, S. Forest Health; US Department of Agriculture, Forest Service, Washington Office: Washington, DC, USA, 2009.

52. Anonymous. Sustaining the world's forest: The Santiago agreement. J. Forest. 2005, 93, 18-21.

53. Zhao, W.; Fang, X.M.; Wei, Y.W.; Lewis, B.J.; Dai, L.M. Evaluation on the forest ecosystem service function value. Adv. Inf. Sci. Serv. Sci. 2012, 22, 495-502.

54. Kolb, T.E.; Wagner, M.R.; Covington, W.W. Concepts of forest health: utilitarian and ecosystem perspectives. J. Forest. 1994, 92, 10-15.

55. Prambudia, Y.; Nakano, M. Integrated simulation model for energy security evaluation. Energies 2012, 5, 5086-5110.

56. Tyrvainen, L.; Uusitalo, M.; Silvennoinen, H.; Hasu, E. Towards sustainable growth in nature-based tourism destinations: Clients' views of land use options in Finnish Lapland. Landscape Urban. Plan. 2014, 122, 1-15.

57. Gaoue, O.G.; Horvitz, C.C.; Ticktin, T. Non-timber forest product harvest in variable environments: Modeling the effect of harvesting as a stochastic sequence. Ecol. Appl. 2011, 21, 1604-1616.

58. Foley, J.A.; Defries, R.; Asner, G.P.; Barford, C.; Bonan, G.; Carpenter, S.R.; Chapin, F.S.; Coe, M.T.; Daily, G.C.; Gibbs, H.K.; et al. Global consequences of land use. Science 2005, 309, 570-574.

59. Kauppi, P.E.; Ausubel, J.H.; Fang, J.Y.; Mather, A.S; Sedjo, R.A.; Waggoner, P.E. Returning forests analyzed with the forest identity. Proc. Natl. Acad. Sci. USA 2006, 103, 17574-17579.

60. Liu, C.F.; Li, X.M. Carbon storage and sequestration by urban forests in Shenyang, China. Urban For. Urban. Green. 2012, 11, 121-128.

61. Alig, R.J.; Bair, L.S. Forest environmental investments and implications for climate mitigation. J. Environ. Qual. 2006, 35, 1389-1395.

62. Helin, T.; Holma, A.; Soimakallio, S. Is land use impact assessment in LCA applicable for forest biomass value chains? Findings from comparison of use of Scandinavian wood, agro-biomass and peat for energy. Int. J. Life Cycle Assess. 2014, 19, 770-785.

63. Rauman, C.G.; Cablk, M.E. Change in the forested and developed landscape of the Lake Tahoe basin, California and Nevada, USA, 1940-2002. Forest. Ecol. Manag. 2008, 255, 3424-3439.

64. Robert, M.E. Interaction effects between economic development and forest cover determine deforestation rates. Global Environ. Chang. 2006, 16, 161-169. 
65. Martell, D.L.; Gunn, E.A.; Weintraub, A. Forest management challenges for operational researchers. Eur. J. Oper. Res. 1998, 104, 1-17.

66. Crandall, R.W. Controlling Industrial Pollution: The Economics and Politics of Clean Air; Brookings institution: Washington, DC, USA, 1983.

67. Oren, R.; Ellsworth, D.S.; Johnsen, K.H.; Phillips, N.; Ewers, B.E.; Maier, C.; Schäfer, K.V.R.; McCarthy, H.; Hendrey, G.; McNulty, S.G.; Katul, G.G. Soil fertility limits carbon sequestration by forest ecosystems in a $\mathrm{CO}_{2}$-enriched atmosphere. Nature 2001, 411, 469-472.

68. Grodzińska, K. Acidity of tree bark as a bio indicator of forest pollution in Southern Poland. Water Air Soil Poll. 1977, 8, 3-7.

69. Jost, G.; Heuvelink, G.B.M.; Papritz, A. Analysing the space-time distribution of soil water storage of a forest ecosystem using spatio-temporal kriging. Geoderma 2005, 123, 258-273.

70. McGinnis, M.D.; Ostrom, E. Social-ecological system framework: Initial changes and continuing challenges. Ecol. Soc. 2014, doi: 10.5751/ES-06387-190230.

71. Wu, K.Y.; Jin, J.L. Attribute recognition method of regional ecological security evaluation based on combined weight on principle of relative entropy. Sci. Geogr. Sin. 2008, 28, 754-758. (In Chinese)

72. Mon, D.L.; Cheng, C.H.; Lin, J.C. Evaluation weapon system using fuzzy analytic hierarchy process based on entropy weight. Fuzzy Set. Syst. 1994, 62, 127-134.

73. Li, S.; Wei, H.; Ni, X.L.; Gu, Y.W.; Li, C.X. Evaluation of urban human settlement quality in Ningxia based on AHP and entropy method. J. Appl. Ecol. 2014, 25, 2700-2708.

74. Ross, D.C.; Richard, D.N.; João, C.; Tiago, O.; Abílio, P.P. Forest fire management to avoid unintended consequences: A casestudy of Portugal using system dynamics. J. Environ. Manag. 2013, 130, 1-9.

75. Wu, Y.N.; Chen, K.F.; Yang, Y.S.; Feng, T.T. A system dynamics analysis of technology, cost and policy that affect the market competition of shale gas in China. Renew. Sustain. Energ. Rev. 2015, 45, 235-243.

76. Mbairamadji, J. Ecosystemic forest management approach to ensure forest sustainability and socio-economic development of forest dependent communities: Evidence from Southeast Cameroon. Field Actions Sci. Rep. 2009, 3, 1-7.

77. Wang, G.Y.; Innes, J.L.; Lei, J.F.; Dai, S.Y.; Wu, S.W. China's forestry reforms. Science 2008, 318 , 1556-1557.

78. Derkyi, M.A.A. Fighting over Forest: Interactive Governance of Conflicts over Forest and Tree Resources in Ghana's High Forest Zone; African Studies Centre: Leiden, The Netherlands, 2012; pp. 262-290.

79. Bradley, G.A. Land Use and Forest Resources in a Changing Environment, 1st ed.; University of Washington Press: Washington, DC, USA, 1984; p. 28.

80. China Daily. Available online: http://www.chinadaily.com.cn/opinion/2014-10/10/content 18716671.htm (accessed on 10 October 2014).

81. Wang, A.S. The Report on the Work of the Government of Beijing (2014); The People's Government of Beijing: Beijing, China, 2014. Available online: http://news.qq.com/a/20140116/ 010936.htm (accessed on 16 January 2014).

82. Peng, Z.H. Beijing Forestry Development Strategy; China Forestry Publishing House: Beijing, China, 2007. 
83. People's Daily. Available online: http://www.people.com.cn/GB/shizheng/19/20020802/ 790307.html (accessed on 2 August 2002).

(C) 2015 by the authors; licensee MDPI, Basel, Switzerland. This article is an open access article distributed under the terms and conditions of the Creative Commons Attribution license (http://creativecommons.org/licenses/by/4.0/). 